\title{
Mesozooplankton grazing minimally impacts phytoplankton abundance during spring in the western North Atlantic
}

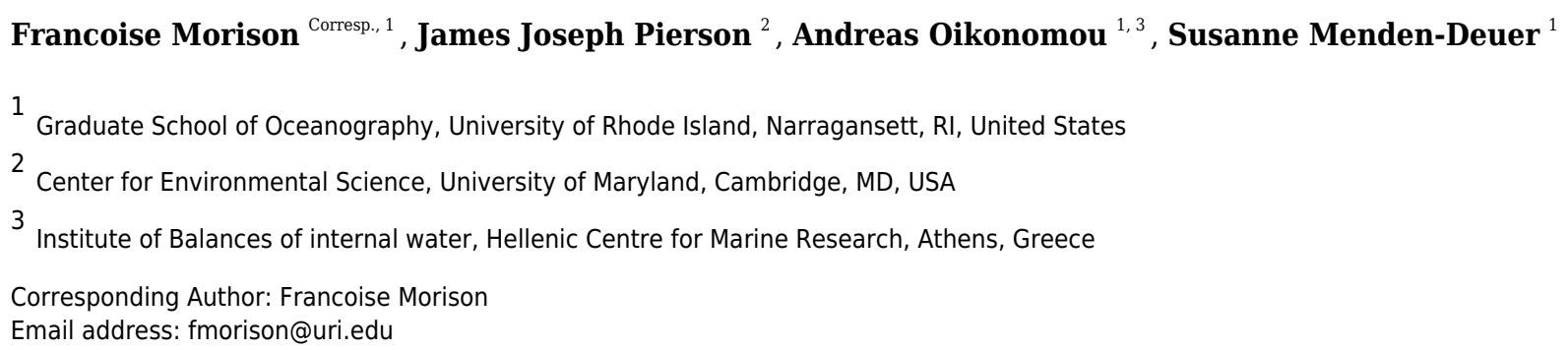

The impacts of grazing by meso- and microzooplankton on phytoplankton primary production (PP) was investigated in the surface layer of the western North Atlantic during spring. Shipboard experiments were performed on a latitudinal transect at three stations that differed in mixed layer depth, temperature, and mesozooplankton taxonomic composition. The mesozooplankton community was numerically dominated by Calanus finmarchicus at the northern and central station, with Calanus hyperboreus also present at the northern station. The southern station was $>10^{\circ} \mathrm{C}$ warmer than the other stations and had the most diverse mesozooplankton assemblage, dominated by small copepods including Paracalanusspp. Microzooplankton grazing was detected only at the northern station, where it removed $97 \%$ of PP. Estimated clearance rates by $C$. hyperboreusand $C$. finmarchicussuggested that at in-situ abundance these mesozooplankton were not likely to have a major impact on phytoplankton abundance, unless locally aggregated. Although mesozooplankton grazing impact on total phytoplankton was minimal, these grazers completely removed the numerically scarce $>10 \mu \mathrm{m}$ particles, altering the particle-size spectrum. At the southern station, grazing by the whole mesozooplankton assemblage resulted in a removal of $14 \%$ of PP, and its effect on net phytoplankton growth rate was similar irrespective of ambient light. In contrast, reduction in light availability had an approximately 3-fold greater impact on net phytoplankton growth rate than mesozooplankton grazing pressure. The low mesozooplankton grazing impact across stations suggests limited mesozooplankton-mediated vertical export of phytoplankton production. The constraints provided here on trophic transfer, as well as quantitative estimates of the relative contribution of light and grazer controls of PP and of grazerinduced shifts in particle size spectra, illuminate food web dynamics and aid in parameterizing modeling-frameworks assessing global elemental fluxes and carbon export. 
$1 \quad$ Mesozooplankton grazing minimally impacts phytoplankton

2

3

$6{ }^{1}$ University of Rhode Island, Graduate School of Oceanography, Narragansett, Rhode Island, 7 USA

$8 \quad 2$ University of Maryland, Center for Environmental Sciences, Cambridge, Maryland, USA

$9{ }^{3}$ Present address: Institute of Balances of internal water, Hellenic Centre for Marine Research, 10 Athens, Greece

*Correspondence:

13 Françoise Morison

14 South Ferry Road, Narragansett, RI, 02882, USA

15 fmorison@uri.edu 
17

18

19

20

21

22

23

24

25

26

27

28

29

30

31

32

33

34

35

36

37

38

39

40

41

42

43

44

45

46

47

48

49

50

51

52

53

54

55

56

57

58

59

60

61

62

63

\section{Abstract}

The impacts of grazing by meso- and microzooplankton on phytoplankton primary production (PP) was investigated in the surface layer of the western North Atlantic during spring. Shipboard experiments were performed on a latitudinal transect at three stations that differed in mixed layer depth, temperature, and mesozooplankton taxonomic composition. The mesozooplankton community was numerically dominated by Calanus finmarchicus at the northern and central station, with Calanus hyperboreus also present at the northern station. The southern station was $>10^{\circ} \mathrm{C}$ warmer than the other stations and had the most diverse mesozooplankton assemblage, dominated by small copepods including Paracalanus spp. Microzooplankton grazing was detected only at the northern station, where it removed $97 \%$ of PP. Estimated clearance rates by $C$. hyperboreus and $C$. finmarchicus suggested that at in-situ abundance these mesozooplankton were not likely to have a major impact on phytoplankton abundance, unless locally aggregated. Although mesozooplankton grazing impact on total phytoplankton was minimal, these grazers completely removed the numerically scarce $>10 \mu \mathrm{m}$ particles, altering the particle-size spectrum. At the southern station, grazing by the whole mesozooplankton assemblage resulted in a removal of $14 \%$ of PP, and its effect on net phytoplankton growth rate was similar irrespective of ambient light. In contrast, reduction in light availability had an approximately 3 -fold greater impact on net phytoplankton growth rate than mesozooplankton grazing pressure. The low mesozooplankton grazing impact across stations suggests limited mesozooplankton-mediated vertical export of phytoplankton production. The constraints provided here on trophic transfer, as well as quantitative estimates of the relative contribution of light and grazer controls of PP and of grazer-induced shifts in particle size spectra, illuminate food web dynamics and aid in parameterizing modeling-frameworks assessing global elemental fluxes and carbon export.

\section{Introduction}

Zooplankton occupy a pivotal position in pelagic food webs. Grazing by zooplankton represents the major fate of marine phytoplankton production (Banse, 2013; Steinberg \& Landry, 2017), influencing energy transfer to higher trophic levels, nutrient cycling, and carbon flow. As important herbivores, zooplankton act as key mediators of the biological pump that contributes to the ocean drawdown of carbon from the atmosphere (Ducklow, Steinberg \& Buesseler, 2001). In the North Atlantic, grazing by zooplankton has been identified as an important factor influencing the formation, timing, and magnitude of the spring bloom (Riley, 1946; Cushing, 1959; Evans \& Parslow, 1985; Banse, 1994; Behrenfeld \& Boss, 2014). Empirical quantification of herbivorous zooplankton feeding rates is therefore crucial to understanding phytoplankton blooms, trophic linkages, and biogeochemical cycles.

Among the extremely diverse zooplankton assemblage, the micro- $(20-200 \mu \mathrm{m})$ and meso- $(200 \mu \mathrm{m}-20 \mathrm{~mm})$ size classes (Sieburth, Smetacek \& Lenz, 1978) are recognized as the major grazers of phytoplankton (Steinberg \& Landry, 2017). Microzooplankton are predominantly represented by herbivorous protists with rapid doubling rates on the order of one or a few days, many of which function as mixotrophs (Stoecker et al., 2017). Mesozooplankton are a functionally diverse group of metazoan grazers that is largely composed of copepods (Turner, 2004) and occupies multiple trophic levels in planktonic food webs (Calbet \& Saiz, 2005; Saiz \& Calbet, 2011). Compared to microzooplankton, mesozooplankton have generation times on the order of weeks and months and are numerically less abundant (Schmoker, 
64 Hernández-León \& Calbet, 2013). Thus, due to their capacity to reproduce asexually,

65

66

67

68

69

70

71

72

73

74

75

76

77

78

79

80

81

82

83

84

85

86

87

88

89

90

91

92

93

94

95

96

97

98

99

100

101

102

103

104

105

106

107

108

109 microzooplankton are thought to increase in biomass faster than mesozooplankton in response to the increase in phytoplankton biomass such as occurs during the formation of a bloom (Sherr et al., 2003, Sherr \& Sherr, 2009). While mesozooplankton grazing on oceanic primary production (PP) can occasionally be high (Calbet, 2001), microzooplankton generally tend to exert a higher grazing pressure on PP than mesozooplankton (Calbet, 2008; Calbet et al., 2009; Campbell et al., 2009).

Feeding by planktonic herbivores is controlled by multiple factors including feeding mode, motility, and grazer and prey sizes (Hansen, Tande \& Berggreen, 1994; Kiørboe, 2011; Wirtz, 2012). Herbivorous protists' diverse feeding strategies (e.g. pallium feeding of dinoflagellates, Menden Deuer et al., 2005) allow them to access a range of prey sizes spanning from bacteria to chain-forming phytoplankton (Sherr \& Sherr, 2002; Sherr, Sherr \& Ross, 2013). Nonetheless, grazing rates by herbivorous protists tend to be lower on large cells than on smaller components of the phytoplankton community (e.g. Burkill et al., 1987; Verity et al., 1996). Copepods have been shown to selectively ingest cells based on size, with lower ingestion rates for both the smallest and largest cells (e.g. Gonçalves et al., 2014). Feeding on large cells is, however, more efficient, as more biomass is ingested per cell, which may favor copepod feeding on large cells (Frost, 1972). Although large grazers such as copepods are usually considered to feed on larger particles than microzooplankton, micro- and mesozooplankton also select among similarly sized food-particles, distinguishing prey characteristics such as nutrient composition, phylogeny, and chemical traits (Löder et al., 2011, Meunier et al., 2015).

There is increasing evidence that many copepods, including smaller species such as Oithona spp. and Paracalanus spp., as well as naupliar stages of larger copepods such as Calanus spp., feed primarily on heterotrophic protists rather than on phytoplankton (Turner, 2004; Calbet \& Saiz, 2005; Campbell et al., 2009; Saiz \& Calbet, 2011; Stoecker \& Pierson, 2019). Copepod feeding on these microzooplankton may suppress protistan grazing impact through top-down control on protistan abundance (Nejstgaard et al., 2001). Such a trophic cascade can reduce all grazer-driven phytoplankton mortality, which results in higher net phytoplankton growth rates and can lead to phytoplankton biomass accumulation (Leising et al., 2005a; Olson et al., 2006; Lavrentyev et al., 2015). Trophic cascades can shift the fate of PP from trophic transfer to export, through the sinking of unconsumed phytoplankton due to nutrient depletion (Schmoker, Hernández-León \& Calbet, 2013), export via fecal pellets or via vertical migration of zooplankton (Steinberg et al., 2000; Gleiber, Steinberg \& Ducklow, 2012; Siegel et al. 2016), or physical processes such as subduction of surface waters with high phytoplankton concentrations (Omand et al., 2015).

Despite the recognized importance of grazing as a factor controlling phytoplankton biomass and its fate, in the North Atlantic the realized rates of grazing, the relative contribution of micro- vs. mesozooplankton, and the effects of environmental and biological conditions on grazing are poorly constrained (Morison \& Menden Deuer, 2015), which limits predictive capacity of these key factors in understanding the spring bloom, and ultimately its contribution to the global carbon cycle and how it may be affected by climate related changes in ocean conditions. The North Atlantic Aerosols and Marine Ecosystems Study (NAAMES) was an interdisciplinary investigation aimed at resolving key environmental and ecological processes controlling North Atlantic plankton communities, the annual cycle of PP, as well as their linkage to marine aerosols. The western North Atlantic NAAMES study region has been less studied than its eastern counterpart, and as a result is less well characterized with respect to plankton 
110 abundance, distribution, and food web dynamics (Behrenfeld et al., 2019). During NAAMES

111 four campaigns, we routinely quantified rates of phytoplankton growth and microzooplankton-

112 induced mortality, a subset of which has been published (Morison et al., 2019). The main

113 objective of the work presented here was to estimate phytoplankton losses due to

114 mesozooplankton grazing during the NAAMES spring campaign (May 2016). At three

115 physically and biologically distinct sampling sites of the study region, in parallel with routine

116 microzooplankton measurements, we opportunistically quantified the grazing impact of

117 mesozooplankton, including two taxa of common north Atlantic calanoid copepods (Calanus

118 hyperboreus and Calanus finmarchicus), and a taxonomically diverse mesozooplankton

119 community dominated by small copepods, including Paracalanus spp. Light manipulation was

120 performed at one station to investigate the role of light in the balance between phytoplankton

121 growth and losses. Our findings suggest that feeding by large herbivorous copepods only had a

122 minimal impact on PP but did alter the particle size spectrum, and that the effect of light

123 availability on phytoplankton growth controlled phytoplankton accumulation to a greater extent

124

125

126

127

128

129

130

131

132

133

134 than grazing by a community of small metazoan herbivores.

\section{Materials and Methods}

\section{Study area}

Zooplankton grazing experiments were conducted aboard the R/V Atlantis on May 19, 21, and 27 respectively at three stations (S1, S2, and S4) located in the western North Atlantic ocean along a north to south transect $\left(54-44^{\circ} \mathrm{N}, \sim 40^{\circ} \mathrm{W}\right.$ ) (Figure 1). The sequence of station numbers follows the numbering pattern during the NAAMES cruise to facilitate comparisons with other research from the field campaign. The western North Atlantic is a physically highly variable region, characterized by a complex mesoscale and sub-mesoscale eddy field (Della Penna \& Gaube, 2019). S1 was located within a cyclonic eddy, and S2 and S4 occupied anticyclonic eddies, with S2 sampling occurring in the eddy core, and S4 sampling occurring on the eddy periphery.

\section{Experimental set-up}

Water for the experiments was collected pre-dawn using a CTD rosette with $10 \mathrm{~L}$ Niskin bottles. The rosette was equipped with a SBE911plus (Seabird Electronics), a SBE43 oxygen sensor, a Wetlabs C-Star transmissometer, and a Wet Labs FLNTURTD combination fluorometer and turbidity sensor. Water collection depths were $18 \mathrm{~m}, 11 \mathrm{~m}$, and $5 \mathrm{~m}$ at S1, S2, and S4 respectively, and were always within the mixed layer (Table 1), with mixed layer depth calculated according to the temperature algorithm as described in Holte \& Talley (2009). Whole seawater (WSW) was gently transferred from the Niskin bottles into $10 \mathrm{~L}$ or $20 \mathrm{~L}$ carboys through silicone tubing fitted with $200 \mu \mathrm{m}$ mesh over the end to exclude larger grazers.

To measure rates of microzooplankton grazing, we used the Landry \& Hasset (1982) recognized as a reliable alternative to the traditional dilution series (Chen, 2015; Morison \& Menden-Deuer, 2017) and has been used successfully in many studies (e.g. Worden \& Binder, 2003; Strom \& Fredrickson, 2008; Landry et al., 2008, 2009, 2011; Lawrence \& Menden-Deuer, 2012; Menden-Deuer, Lawrence \& Franzè, 2018). Methods are presented in detail in a companion paper (Morison et al., 2019). In brief, the two dilutions used were $100 \%$ and $20 \%$ $<200 \mu \mathrm{m}$ WSW. The filtered seawater (FSW) needed for the $20 \% \mathrm{WSW}$ dilution was obtained by filtering seawater directly from the Niskin bottles through a $0.45 \mu \mathrm{m}$ membrane filter capsule 
157 (Pall). Each dilution treatment was prepared in a carboy, and gently siphoned through silicone 158 tubing from the carboys into $1.2 \mathrm{~L}$ polycarbonate bottles. Duplicate bottles of each dilution were 159 amended with a final concentration of $10 \mu \mathrm{M}$ of both nitrate and silicate, and $1 \mu \mathrm{M}$ of phosphate.

160 An additional set of duplicate $100 \%$ WSW bottles was prepared without adding nutrients to serve 161 as a nutrient control.

Mesozooplankton grazing was measured in incubations paired with the dilution assays (Figure S1). The mesozooplankton experiments were performed using either additions of discrete numbers of handpicked copepods (S1 and S2) or a whole mesozooplankton assemblage (S4). Copepods for discrete copepod additions were collected at midnight from the upper $15 \mathrm{~m}$ of the water column with a vertical net tow using a $1 \mathrm{~m}$ diameter ring net fitted with $220 \mu \mathrm{m}$ mesh and a non-filtering cod-end. To minimize stress on the animals, as soon as the copepod net was retrieved, the content of the cod-end was diluted into buckets containing unfiltered (S1) or filtered (S2) surface seawater. Individual undamaged copepods were selected under a dissecting microscope using wide-bore pipettes and were placed into $30 \mathrm{~mL}$ vials until all incubation bottles were filled. Actively swimming copepods were transferred to $1.2 \mathrm{~L}$ polycarbonate bottles containing $<200 \mu \mathrm{m} \mathrm{WSW}$. The remainder of the sample from each net tow was preserved in ethanol (10\% final concentration). All fixed samples were later sorted under a stereo dissecting microscope to identify species, estimate abundances, sex, and stage distribution of copepods, accounting for those that were removed for the experiments. Animals were identified to the lowest possible taxonomic level (species for Calanus spp., genus for other copepods, various levels for other taxa).

Taxa used in discrete experiments were determined based on copepods observed abundance and ease of sorting. In order to measure detectable feeding rates and reduce the possibility of the copepods clearing all particles from the whole bottle, we chose the number of copepods per bottle based on expected per capita clearance rates, such that the copepods in the bottles would not be expected to clear more than $30-40 \%$ of the volume in the bottles (Gifford, 1993). A range of copepod concentrations was used to bracket the potential variability in feeding rates. At S1, feeding experiments were conducted using $C$. hyperboreus despite the species not being the most abundant, because based on its reported distribution range, it was expected that its prevalence would decrease at more southern stations, preventing further investigation. Adult individuals, known to range in size from 5-7 mm (Leinaas et al., 2016), were added to the incubation bottles at concentrations of 1, 3, or 5 individuals per bottle. At S2, adult individuals of C. finmarchicus were used. Based on this species' smaller size (2.5-2.7 mm; Leinaas et al., 2016), 10, 20, and 40 individuals $\mathrm{L}^{-1}$ were added. At S4, net tows revealed the dominance of small $(<1 \mathrm{~mm})$ metazoa that would be difficult to sort by hand, as done for S1 and S2. Hence some whole seawater was collected without the $200 \mu \mathrm{m}$ screening mesh so as to include mesozooplankton. Incubations of this unscreened whole seawater served as the experimental treatment representing the mesozooplankton assemblage at concentrations occurring in situ.

Discrete copepod additions were incubated in duplicate for each copepod concentration, and unscreened WSW including the mesozooplankton assemblage used at S4 was incubated in triplicates (Figure S1). In all experiments, no nutrients were added to the bottles containing the mesozooplankton. Incubations for all experiments lasted $24 \mathrm{~h}$ so as to encompass grazers' possible diel feeding cycle. Bottles were placed in $250 \mathrm{~L}$ on-deck plexiglass incubators kept at ambient temperature using an open-circuit flow of surface seawater. Neutral density screening was used to maintain incubations at light intensities targeted to correspond to in situ light intensity at the collection depth, approx. $10 \%$ of surface irradiance at S1 and S2, and $40 \%$ of 
203 surface irradiance at S4. At S4, to ensure compatibility with S1 and S2, to estimate potential high

204 irradiance effects on mesozooplankton, and to quantify the light dependence of phytoplankton

205 growth and mortality due to mesozooplankton grazing, additional duplicate bottles of $<200 \mu \mathrm{m}$

206 WSW and triplicate bottles of unscreened WSW were incubated without added nutrients at an

207 additional light intensity of $10 \%$ surface irradiance, which corresponded to the in situ light at a

$208 \sim 20 \mathrm{~m}$ depth. The percentage of light reduction achieved with the neutral density screening was

209 measured with a QSL-2100 Scalar irradiance sensor (Biospherical Instruments Inc.) and verified

210 using a Hobo (onset) data logger placed in the incubators that recorded light intensity at $1 \mathrm{~min}$

211 intervals. To keep all bottles in an experiment exposed to an even light intensity, bottles were

212 suspended from a line running across the incubators, which, along with the combined effect of

213

214

215

216

217

218

219

220

221

222

223

224

225

226

227

228

229

230

231

232

233

234

235

236

237

238

239

240

241

242

243

244

245

246

247

248

249

\section{Rate estimates}

Zooplankton grazing rates were estimated from changes in chlorophyll a (Chl a) over the incubation duration. For each experiment, $\mathrm{Chl}$ a concentration $(\mathrm{P})$ was determined from triplicate $180 \mathrm{~mL}$ subsamples of initial stock $\left(\mathrm{P}_{0}\right)$ and of each replicate incubation bottle $\left(\mathrm{P}_{\mathrm{t}}\right)$ filtered over $0.7 \mu \mathrm{m}$ glass microfiber filters (Whatman $\mathrm{GF} / \mathrm{F}$ ). Chl a determination followed Graff \& Rynearson (2011), except that extraction took place at room temperature and in the dark for 12$15 \mathrm{~h}$ in $96 \%$ ethanol (Jespersen \& Christoffersen, 1987).

Changes in light conditions between in situ and incubations can induce phenotypic responses of phytoplankton cells known as photoacclimation (Gutiérrez-Rodríguez et al., 2010 and references therein). The photoacclimation process can introduce artifacts in the estimation of phytoplankton growth rates due to changes in phytoplankton cells' pigment content and therefore in the Chl a to carbon ratio in response to a change of light (Ross et al., 2011). To avoid such artifacts, a photoacclimation index (Phi) was estimated following Gutierrez-Rodriguez et al. (2010, 2011) and Morison et al. (2019), using flow cytometry (FC) data obtained from $200 \mu \mathrm{L}$ aliquots of $<40 \mu \mathrm{m}$ screened WSW analyzed live on a Guava ${ }^{\circledR}$ easyCyte Flow Cytometer. FC data were collected as previously described in Morison et al. (2019). Samples were run at $0.24 \mu 1$ $\mathrm{s}^{-1}$ for $3 \mathrm{~min}$. Three phytoplankton groups (Synechococcus spp., pico- and nanoeukaryotes) were distinguished based on their forward scatter and red (695/50) emission parameters with $488 \mathrm{~nm}$ excitation, and orange (620/52) emission parameters with $532 \mathrm{~nm}$ excitation. For each sample, we calculated a photoacclimation index (Phi) from initial and final FC measurements of red fluorescence to forward scatter ratio (FLR:FSC), the latter being used as a proxy for Chl a:carbon (Graff \& Behrenfeld 2018). Phi values $<1$ indicate a decrease in the FRL:FSC ratio (i.e., less Chl a per unit of biomass), values $>1$ indicate an increase in the ratio (more $\mathrm{Chl}$ a per unit of biomass), and values $=1$ indicate no change.

Rates of phytoplankton growth and microzooplankton grazing were estimated as previously described in Morison et al. (2019). Net phytoplankton growth rate $\left(k, \mathrm{~d}^{-1}\right)$ in each experimental bottle was estimated using the equation $k=1 / \mathrm{t} \times \ln \left(\left[\mathrm{P}_{\mathrm{t}} / \mathrm{Phi}\right] / \mathrm{P}_{0}\right)$, where $\mathrm{t}$ is the duration of the incubation in days, and with final $\mathrm{Chl}$ a concentration $\left(\mathrm{P}_{\mathrm{t}}\right)$ corrected for photoacclimation-derived changes in cell pigment content using Phi. For S4, missing data prevented estimation of Phi, thus rates for that station were not adjusted for photoacclimation. Microzooplankton grazing rates $\left(g, \mathrm{~d}^{-1}\right)$ were estimated using $k$ values from nutrient amended replicates using the equation $g=\left(k_{d i l}-k_{1}\right) /(1-\mathrm{D})$ in which the subscripts dil and 1 correspond to the nutrient-amended diluted and undiluted treatments respectively, and $\mathrm{D}$ represents the achieved fraction of WSW in the diluted treatment, as determined from measured initial Chl a concentration. A model I linear regression of $k$ as a function of dilution was used to determine

Peer) reviewing PDF | (2020:02:45907:2:0:NEW 2 Jun 2020) 
250 whether grazing was significantly different from zero $(\alpha \leq 0.05)$, and to yield the standard error of 251 the grazing rate estimate. Phytoplankton in situ specific growth rates $\left(\mu, \mathrm{d}^{-1}\right)$ were determined as 252 the sum of the grazing rate $\left(g, \mathrm{~d}^{-1}\right)$ and the mean net growth rate of the non-amended $<200 \mu \mathrm{m}$ 253 WSW bottles. Negative values of grazing rates, which result when the phytoplankton apparent 254 growth rate $(k)$ is lower in the diluted than in the undiluted treatments, indicate a violation of a 255

256

257

258

259

260

261

262

263

264 central assumption of the dilution method (Landry \& Hassett, 1982). Thus in case of statistically significant negative grazing rates, losses were undetermined, and in the absence of a grazing loss estimate, $\mu$ was equated to the net growth rate $(k)$ in the undiluted non-amended bottles.

For S1 and S2, copepod clearance rates for C. hyperboreus and $C$. finmarchicus based on bulk Chl a measurements were calculated as described previously (Leising et al., 2005b). Briefly, the net phytoplankton growth rates $(k)$ in the copepod additions and the microzooplankton-only control were regressed against the concentration of copepods in each treatment, with the $100 \%$ $<200 \mu \mathrm{m}$ seawater treatment from the microzooplankton dilution experiments used as "zero" copepod treatment. The slope of the regression line is equivalent to the per capita daily grazing rate of copepods on $\mathrm{Chl} \mathrm{a}$. Negative slopes of this regression indicate removal of $\mathrm{Chl}$ a through copepod feeding. Specific grazing rates were converted to clearance rates using the relationship of $F=V g / N$, where $F$ is the clearance rate $\left(\mathrm{mL}\right.$ individual $\left.{ }^{-1} \mathrm{~d}^{-1}\right), \mathrm{V}$ is the volume of the experimental container $(\mathrm{mL}), g$ is the grazing rate $\left(\mathrm{d}^{-1}\right)$, and $\mathrm{N}$ is the number of copepods (Frost, 1972). Copepod viability was verified for all incubation bottles at the end of the experiments. Corrections for copepod mortality were not necessary, because all individuals except one $C$. hyperboreus in a bottle with 5 copepods were found to be actively swimming at the end of the incubation period.

For S4, total phytoplankton mortality due to the combined effects of micro- and mesozooplankton grazing was calculated by subtracting the net phytoplankton growth rate $(k)$ in the unscreened WSW bottles from $\mu$. Mesozooplankton grazing rates were then calculated as the difference between total and microzooplankton-induced mortality rates.

In order to estimate grazing effects on particle size abundance spectra, particle abundances between 3 and $60 \mu \mathrm{m}$ equivalent spherical diameter (ESD) were determined from 2 $\mathrm{mL}$ samples collected from initial stock and from all bottles at the end of the incubation period and analyzed with a Multisizer ${ }^{\mathrm{TM}} 3$ Coulter Counter ${ }^{\circledR}$ (Beckman Coulter, USA). A FSW sample was also analyzed and served as a correction blank. Blank controls contained a negligible amount of particles, with a coefficient of variation of $1 \%$. Significant difference in particle size abundance spectra for the copepod treatments relative to the microzooplankton-only control was assessed with a 2-sample Kolomogorov-Smirnov test at a significance level of $\mathrm{p}<0.05$.

\section{Results}

Each station had distinctive physical characteristics reflective of its latitudinal location and the mesoscale feature it occupied (Figure 1). Mixed layer depth was $56 \mathrm{~m}, 41 \mathrm{~m}$, and $22 \mathrm{~m}$ at $\mathrm{S} 1, \mathrm{~S} 2$, and S4 respectively. Mixed-layer average water temperature ranged from $3.9^{\circ} \mathrm{C}$ at $\mathrm{S} 1$ to $15.5^{\circ} \mathrm{C}$ at S4 (Figure 2). Mixed-layer average salinity ranged from 34.58 at S2 to 36.13 at S4 (Figure 2). Chl a concentration in the source water, i.e. in situ concentration at sampling depth for the incubation experiments, ranged from $1.4( \pm 0.09) \mu \mathrm{g} \mathrm{L}^{-1}$ at $\mathrm{S} 4$ to $2.7( \pm 0.11) \mu \mathrm{g} \mathrm{L}^{-1}$ at S2 (Table 1). Collection depth for source water and copepods was within the surface mixed layer, well shallower than the mixed layer depth (Figure 2). Copepod community composition differed between stations (Figure 3). C. finmarchicus was present at all stations, and was numerically dominant at S1 and S2 (Table S1). C. hyperboreus was only present at S1. The most diverse 
297 assemblage was collected at S4, dominated by C. finmarchicus, Paracalanus spp., and

298 Pleuromamma spp., but also including Pseudocalanus spp. Metridia lucens, and several other

299 taxa.

300

301

302

303

\section{Effect of micro- and mesozooplankton grazing on phytoplankton growth}

Microzooplankton grazing was limited to the most northern station (S1), where microzooplankton grazing rate was $0.38 \pm 0.06 \mathrm{~d}^{-1}$ and phytoplankton specific growth rate $(\mu)$ was $0.39 \pm 0.09 \mathrm{~d}^{-1}$. Thus micro-grazers at S1 consumed almost all (97\%) PP (Table 1). No significant microzooplankton grazing was detected at S2 (Table S2), where $\mu$ was $0.61 \pm 0.08 \mathrm{~d}^{-1}$. At S4, microzooplankton grazing measurement was conducted at the in situ light level only. The net phytoplankton growth rate $(k)$ in the $20 \%$ WSW dilution was lower than in any of the WSW treatments (Table S2), representing a violation of one of the method's central assumptions, i.e. that $\mu$ is constant across dilutions (Landry \& Hasset 1982). Thus at S4, the microzooplankton grazing rate could not be determined, and the net growth rate in the $<200 \mu \mathrm{m}$ WSW without added nutrients $\left(0.59 \pm 0.08 \mathrm{~d}^{-1}\right)$ was considered to represent in situ $\mu$.

At both S1 and S2, mesozooplankton feeding on phytoplankton was indicated by the decreasing net phytoplankton growth rate $(k)$ with increasing numbers of copepods (Figure 4). At $\mathrm{S} 1, k$ was significantly inversely related to grazers' abundance (Model I regression, $\mathrm{df}=6, \mathrm{p}=$ 0.027). Net phytoplankton growth was highest in the incubation where only microzooplankton grazers were present $\left(0.01 \pm 0.07 \mathrm{~d}^{-1}\right)$, and decreased with increasing number of copepods added, from $-0.25( \pm 0.21) \mathrm{d}^{-1}$ when one individual of $C$. hyperboreus was added to $-0.40( \pm 0.13) \mathrm{d}^{-1}$ when five individuals were added (Fig. 4a). Similarly, at S2, $k$ was highest when only the microzooplankton fraction was considered $\left(0.61 \pm 0.08 \mathrm{~d}^{-1}\right)$ and decreased significantly (Model I regression, $\mathrm{df}=6, \mathrm{p}=0.0002$ ) with increasing copepod concentrations, ranging from $0.35 \pm 0.26$ $\mathrm{d}^{-1}$ for 10 individuals of $C$. finmarchicus to $-0.53 \pm 0.11 \mathrm{~d}^{-1}$ when 40 individuals were added (Fig. $4 b)$.

Per capita grazing rates were calculated for stations S1 and S2, where experiments were conducted with individual copepods sorted and placed into experimental bottles. For $C$. hyperboreus mean ( \pm standard error) grazing was $0.071( \pm 0.024) \mathrm{d}^{-1}$ at $\mathrm{S} 1$ and for $C$. finmarchicus it was approximately half at $0.029( \pm 0.004) \mathrm{d}^{-1}$ at S2 (Figure 4). Conversion of specific grazing rates resulted in clearance rates of $64.2( \pm 2.2) \mathrm{mL}_{\text {individual }}^{-1} \mathrm{~d}^{-1}$ for $C$. hyperboreus and $30.4( \pm 4.2) \mathrm{mL}_{\text {individual }}{ }^{-1} \mathrm{~d}^{-1}$ for $C$. finmarchicus.

At S4, the relative effect of light vs. mesozooplankton grazing on net phytoplankton growth (k) was quantified by incubating both the microzooplankton $(<200 \mu \mathrm{m}$ WSW) and the whole community of mesozooplankton (unscreened WSW) under a 10\% light intensity representative of a depth of $\sim 20 \mathrm{~m}$, in parallel with the experiment conducted at surface irradiance. Realized mean light intensity in the incubations in the two light treatments was 53\% ( $\pm 5 \%$ SD of the mean of 1 min interval measurements) and $12 \%( \pm 1 \%$ SD) of surface irradiance. Both the consumer group present and the light intensity used in the incubation had an effect on $k$, but the largest effect was observed in response to variations in light intensity (Figure 5). Irrespective of grazer treatment, $k$ was significantly lower (two-way ANOVA, $p=0.0009$ ) in incubations at the $12 \%$ irradiance than at the higher irradiance (Table S3), by $49 \%$ in the microzooplankton-only treatment and $61 \%$ in the copepod addition (Table 1). Irrespective of light treatment, addition of mesozooplankton reduced $k$ by approx. $0.1 \mathrm{~d}^{-1}$ compared to treatments with microzooplankton only (Table 1) but the effect was not significant (two-way ANOVA, $p=0.105$; Table S3). Incubations of whole seawater left unscreened, so as to include mesozooplankton at their in situ abundances, conducted at a light intensity corresponding to the 
344 depth of sample collection, resulted in a $14 \%$ reduction in $k$ relative to the $<200 \mu \mathrm{m}$ control, 345 corresponding to a removal of $14 \%$ of PP (Table 1 ). There was no significant interaction between 346 light intensity and grazer size fraction $(p=0.793)$.

\section{Particle removal by micro- and mesozooplankton.}

An effect of copepod grazing on the size abundance spectrum of particles in the 3-60 $\mu \mathrm{m}$ size range was observed, indicating a shift in size spectra mediated by different grazer communities. Although few particles $>10 \mu \mathrm{m}$ were generally observed, a larger proportion of $>10-15 \mu \mathrm{m}$ particles were removed by mesozooplankton grazers at all stations over the course of the $24 \mathrm{~h}$ incubations, in comparison with microzooplankton-only incubations (Figure 6). Measurably higher particle abundances in the $>10 \mu \mathrm{m}$, and particularly in the $10-20 \mu \mathrm{m}$ size range were observed in microzooplankton-only incubations compared to incubations that contained mesozooplankton grazers. The effect of copepod grazing on particle size distribution was greatest at S2 (Figure 6b), where at concentrations of 20 and 40 C. finmarchicus per bottle, ca. 5-fold lower particle abundances in the 10 to $20 \mu \mathrm{m}$ size range remained after incubation. In contrast, at that same station there was no measurable change in the relative contribution of each size category to total particle abundance in the microzooplankton-only incubations, and size spectra of the initial and final samples were indistinguishable (Figure 6b). This observation is consistent with the lack of detectable microzooplankton grazing at that station.

At S1, the difference between treatments in particle size distribution (PSD) was not significant, either for the entire spectrum (Kolmogorov/Smirnov test, $p=0.62)$ or for $>5 \mu \mathrm{m}(\mathrm{p}=$ $0.56)$ and $>10 \mu \mathrm{m}(\mathrm{p}>0.25)$ particles. However, the analysis was done for the treatment with only one copepod added per bottle, which was likely insufficient to manifest a significant change in particle concentration. At S2, PSD in the copepod treatment was significantly different from the microzooplankton-only treatment $(\mathrm{p}=0.04)$ for particles $>5 \mu \mathrm{m}$ when 40 copepods per bottle where present, and for the $\geq 5 \mu \mathrm{m}$ to $20 \mu \mathrm{m}$ size range when only 20 copepods were added. At $\mathrm{S} 4$, although variable among size bins, the net rate of change in the abundance of particles in the microzooplankton treatment was similar to the $\mathrm{Chl}$ a based net growth rate from the dilution experiment, with an average of $0.6 \mathrm{~d}^{-1}$ for particles 3-30 $\mu \mathrm{m}$, a size fraction representing $99 \%$ of the total counts. Although an increase in particle abundance was observed for most size bins irrespective of the type of grazer, the number of $>5 \mu \mathrm{m}$ particles in the mesozooplankton treatment were reduced relative to the microzooplankton control (Figure 6c) and the difference in PSD between the two treatments was significant $(p=0.04)$.

\section{Discussion}

In many systems, the degree of grazer-induced phytoplankton mortality and the type of grazer largely drive the fate of primary production (Steinberg \& Landry, 2017). Whether organic matter is shuttled to higher trophic levels, recycled within the photic zone, or exported to depth via fecal pellets or other mechanisms, depends on the relative grazing impact of large metazoa and herbivorous protists. Zooplankton grazing is also considered to play a role in the development of phytoplankton blooms (Sherr \& Sherr, 2009), including the formation of the North Atlantic spring bloom (Behrenfeld \& Boss, 2014). In this study, we observed a spatial switch in the relative grazing impact of micro- vs. mesozooplankton. At the most northern S1, microzooplankton were responsible for a high removal of phytoplankton production, whereas larger, mm-sized copepods had a low grazing impact, suggesting a relatively greater rate of biomass recycling in the surface compared to export facilitated by larger specimen that produce 
391 significant fecal pellets and/or vertically migrate (Ducklow, Steinberg \& Buesseler, 2001;

392 Schnetzer \& Steinberg, 2002). At the more southern S2 and S4, grazer-induced losses of primary

393 production were low and essentially due to mesozooplankton. At S2, grazing by

394 microzooplankton was undetectable, and although grazing was undetermined at S4, the high net

395 growth rates of a doubling per day obtained at that station both from $\mathrm{Chl}$ a and particle counts

396 suggest that microzooplankton grazing was minimal. Remarkably, the expected decrease in net

397 phytoplankton growth rates under reduced light at S4 was approximately three times larger than

398 the effect of grazing. The observations presented here may well be restricted to the specific

399 conditions encountered during the study. However, the biological and physical characteristics of

400 the three stations span a considerable dynamic range and the results provide concrete rate

401 estimates and testable hypotheses linking physical features, grazing pressure, light availability,

402 and rates of transfer of matter and energy in the western North Atlantic, where planktonic food

403 web dynamics are poorly characterized.

$404 \quad$ Clearance rates of the large copepods investigated here can vary widely depending on

405 bloom stage, prey availability, and prey type (e.g. Meyers-Harm et al., 1999; Levinsen et al.,

406 2000). The clearance rates presented here fall within the lower end of the published range (e.g.

407 Huntley \& Tande, 1987; Hansen, Tande \& Berggreen, 1990; Nejtsgaard et al., 2001; Mayor et

408 al., 2006), although similar average rates of $25.2 \mathrm{ml} \mathrm{cop}^{-1} \mathrm{~d}^{-1}$ have previously been recorded in

409 the same season and location -May in the North Atlantic- for C. finmarchicus (Gifford et al.,

410 1995). Calculations of the direct impact of C. hyperboreus and C. finmarchicus on PP are

411 problematic with our net tows, which were not designed to quantitatively estimate abundance of

412 these taxa. Nonetheless, considering the clearance rates estimated here, it would require more

413 than $8,000 \mathrm{~m}^{-3}$ C. hyperboreus and $17,000 \mathrm{~m}^{-3}$ C. finmarchicus to clear $100 \%$ of the PP. Even at

414 triple our measured clearance rates, removal of $100 \%$ PP would require much larger copepod

415 concentrations than are generally reported from North Atlantic offshore ecosystems in late

416 spring/early summer (e.g Scott et al., 2000; Madsen, Nielsen \& Hansen, 2001; Heath et al., 2004;

417 Castellani et al., 2008) - although not entirely impossible. Copepods in general tend to spatially

418 aggregate and form patches (Genin et al., 2005; Hirche et al., 2006), and peak abundances of

419 mono-specific aggregations can be up to two orders of magnitude higher than in the water

420 column (Scott et al., 2000; Madsen, Nielsen \& Hansen, 2001; Hirche et al., 2006; Castellani et

421 al., 2008). Although it would be locally restricted, within these patches a higher grazing impact

422 on phytoplankton biomass would be expected, and thus a greater local impact on PP by

423 copepods. It is difficult to assess the quantitative impact of such grazer patches as sizes and

424 frequencies are poorly constrained and variable over time (Basedow et al., 2013).

425

426

427

428

429

430

431

432

433

434

435

Previous studies on the grazing impact of $C$. finmarchicus and $C$. hyperboreus under bloom conditions were often focused on polar waters and estimates have varied considerably among sites. For example, the grazing impact of a Calanus dominated community was estimated to range between $15-93 \%$ of PP in the upper $50 \mathrm{~m}$ of Disko Bay during the main bloom period (Madsen, Nielsen \& Hansen, 2001). In arctic waters, where production is highly restricted seasonally, C. hyperboreus, and C. glacialis grazed $65-90 \%$ of the phytoplankton carbon production (Eilertsen, Tande \& Taasen, 1989). Occasionally, copepods such as C. finmarchicus can suppress bloom development (Williams \& Lindley, 1980; Tiselius, 1988), but grazing of $C$. finmarchicus and C. hyperboreus may not affect PP if their biomass is low (Hirche et al., 1991). Studies focusing on grazing by $C$. finmarchicus have shown the species to have a low grazing impact of 1-10\% of PP (Cowles \& Fessenden, 1995; Gifford et al., 1995). 
436

437

438

439

440

441

442

443

444

445

446

447

448

449

450

451

452

453

454

455

456

457

458

459

460

461

462

463

464

465

466

467

468

469

470

471

472

473

474

475

476

477

478

479

480

481

Although these conclusions come from studies that have focused on particular copepod species, similar conclusions have been drawn from studies of whole mesozooplankton communities. In the North Atlantic ocean, assessments of mesozooplankton grazing during spring bloom events have largely focused on the northeast region (Morales et al., 1991; Dam, Miller \& Jonasdottir, 1993; Lenz, Morales \& Gunkel, 1993; Barquero et al., 1998; Halvorsen et al., 2001), and to the best of our knowledge no data are available for the northwest region, where the present study was conducted. The majority of these studies concluded that phytoplankton biomass in the eastern North Atlantic is underexploited by mesozooplankton communities, with mesozooplankton grazing removing between 3\% (Dam, Miller \& Jonasdottir, 1993) and 14\% PP (Halvorsen et al., 2001). Most studies relied on gut fluorescence analysis and their results are not directly comparable to the methodology applied in our study. In a methodologically similar study to ours using parallel incubations of dilution experiments with and without added copepods, Campbell et al. (2009) measured approximately $13 \%$ removal of PP by copepods in the western Arctic Ocean. Thus, irrespective of the methods used, our results and these prior assessments agree, and all lead to the conclusion that Calanus species have a small impact on PP and are not usually able to suppress bloom development in the North Atlantic.

It has been argued that copepod grazing impact has commonly been underestimated due to the use of nets $>200 \mu \mathrm{m}$ that leave out smaller species and stages of copepods (Turner 2004). In our experiments at S1 and S2, copepods were collected using a $220 \mu \mathrm{m}$ net, thus the grazing impacts presented here are based on the species investigated, assuming their prevalence in the $>220 \mu \mathrm{m}$ mesozooplankton community, and may represent underestimates of the impact on phytoplankton by metazoan grazers as a whole. Some of the smaller $<200 \mu \mathrm{m}$ metazoan specimen are part of the microzooplankton community (Calbet 2008), however the dilution method used to quantify microzooplankton grazing does not allow to distinguish between the small metazoan grazing impact and that of protistan grazers.

The low impact of grazing by copepods on phytoplankton globally has been interpreted as an indication that copepods likely rely on other food sources to supplement their diet (Calbet 2001, Saiz \& Calbet 2011), and indeed microzooplankton can be an important component in the diet of mesozooplankton (Stoecker \& Pierson 2019). High grazing rates and selective feeding by mesozooplankton on microzooplankton in incubations would release microzooplankton grazing pressure on phytoplankton, and thus could lead to an increase in net phytoplankton growth compared to the microzooplankton-only treatments and to an underestimation of copepod grazing rates (Nejstgaard, Gismervik \& Solberg, 1987; Nejstgaard et al., 2001). Here, however, we did not observe the induction of such trophic cascades where higher net phytoplankton growth rates are observed in the presence of copepod grazers, which would have suggested preferential feeding on herbivorous protists. Indeed our calculation of clearance rates indicated direct uptake of phytoplankton for both S1 and S2, which scaled with the concentration of copepods. It is possible that copepods feeding on both phytoplankton and microzooplankton would offset the individual effect on net phytoplankton growth rates of each feeding mode, but at $\mathrm{S} 1$, the only station where microzooplankton grazing was significant, such offset would fail to explain the large differences in net phytoplankton growth between the copepod treatments and the control. It is likely that copepod feeding was omnivorous, and microzooplankton and phytoplankton were grazed by mesozooplankton at proportions similar to their relative abundances (Barquero et al., 1998; Halvorsen et al., 2001).

Despite their low feeding impact on the phytoplankton community as a whole, copepods had a remarkable impact on the particle size spectrum. Although few particles were observed in 
482 the $>10 \mu \mathrm{m}$ size range, these particles were removed only in the presence of copepods. This 483 observation supports the often-observed feeding preference of Calanoid copepods for larger 484 particles (e.g. Frost, 1972; Gifford et al., 1995; Levinsen et al., 2000). Particles $<5 \mu \mathrm{m}$ tend to be

485

486

487

488

489

490

491

492

493

494

495

496

497

498

499

500

501

502

503

504

505

506

507

508

509

510

511

512

513

514

515

516

517

518

519

520

521

522

523

524

525

526

527 too small for these copepods, although very large particles such as diatoms with spines may be too large (Campbell et al., 2009). Copepods, however, demonstrate extensive flexibility in their diet (Kleppel, 1993) and may feed size-selectively when food is abundant, and non-selectively when food becomes scarce (Cowles, 1979). It is possible that if copepods in our incubations fed preferentially on large prey types, these may have been depleted before the end of the experiment, potentially biasing feeding rate estimates. However, due to the low in situ abundance of large particles, feeding on such particles would also be limited in the field. As observed here, size-selective copepod grazing can induce shifts in the size distribution of the plankton community, which may have important implications regarding the potential for particles gravitational sinking and the associated vertical flux of carbon (Stemmann \& Boss, 2012).

In most instances when comparisons between copepod and microzooplankton grazing are possible, the grazing impact by the unicellular herbivores typically exceeds that of the mesozooplankton component at least 2-3 fold (e.g. Morales et al., 1991; Burkill et al., 1993; Dam, Miller \& Jonasdottir, 1993; Weeks et al., 1993; Gifford et al., 1995). In our study, however, the relative grazing impact of both types of grazers varied spatially. At S1, microzooplankton grazing removed $97 \%$ of PP, exceeding the $\sim 66 \%$ estimated global average of the proportion of PP removed by herbivorous protists (Calbet \& Landry, 2004). Perhaps due to their diverse feeding modes, microzooplankton can indeed have a considerable impact on PP. This potential has been documented in the mixed layer of the northeast Atlantic under bloom (Verity et al., 1993) and non-bloom conditions (Burkill et al., 1993), during developing blooms in the polar and subpolar Northeast Atlantic (Morison \& Menden-Deuer, 2015; Menden-Deuer, Lawrence \& Franzè, 2018), and in post-bloom conditions (Gifford et al., 1995). Estimates of the aforementioned studies on daily PP removal by microzooplankton ranged from $15-242 \%$, with the highest average impact ( $81 \%$ ) being attributed to after-bloom conditions (Gifford et al., 1995).

In contrast to the high microzooplankton grazing impact at S1, no microzooplankton grazing was observed at S2 and remained undetermined at S4. Absence of grazing is not uncommon, and has been recorded in all ocean ecosystems, from estuaries to the coastal and open ocean, and in all ocean basins at all latitudes (Schmoker, Hernàndez-Leòn \& Calbet, 2013 and references therein). Lack of grazing could suggest that grazers' biomass had not sufficiently accumulated to have a detectable effect on PP as hypothesized by Sherr \& Sherr (2009). Such biomass buildup can be delayed if grazers have been exposed to prolonged periods of starvation (Anderson \& Menden-Deuer, 2016), which can occur during winter when phytoplankton biomass is low, or when mixing of the ocean surface dilutes plankton populations (Morison et al., 2019). Lack of grazing could also be the result of a mismatch between prey species and grazer feeding types, which can be brought about by frequent physical disturbances occurring in the North Atlantic (Morison \& Menden-Deuer, 2015; Morison et al., 2019). Alternating observations of high grazing impact and of no-grazing have been documented in numerous studies, suggesting an "all or nothing" grazing impact may be characteristic of microzooplankton grazing dynamics (Menden Deuer, Lawrence \& Franzè, 2018 and references within). The negative microzooplankton grazing rates obtained at S4 prevented any estimation of microzooplankton grazing impact. It has been suggested that the presence of chloroplasts in mixotrophs can artificially increase the $\mathrm{Chl}$ a-based apparent growth rate in the undiluted 
528 treatment, resulting in a positive slope (Landry, Constantinou \& Kirshtein, 1995; Calbet et al., 529 2012). Unfortunately the impact -if any- that this process may have had on grazing rate

530 estimation at S4 is difficult to evaluate, as assessing the proportion of mixotrophs in a plankton 531 assemblage that engage in phagotrophy remains challenging (Beisner, Grossari \& Gasol, 2019).

Although our experimental design controlled for light effects on mesozooplankton-

534

535

536

537

538

539

540

541

542

543

544

545

546

547 grazing rates, no such effect was observed in our experiments at S4. Many copepods exhibit diel periodicity in their feeding (Durbin et al., 1990; 1995) that would negate some effects of light, however, under some conditions copepods may feed during daytime (Atkinson et al., 1992). Nonetheless, our observations contrast with previous studies that have shown significantly higher copepod feeding rates at lower irradiances, indicating that light cues may influence both the timing of grazing and the gut fullness in certain copepod species (Stearns, 1986; Cieri \& Stearns, 1999). In contrast, as expected, there was a significant effect of light on phytoplankton growth rates, both in the presence and absence of copepods. Due to differences in phytoplankton growth in response to different light intensity, the mesozooplankton grazing impact on PP estimated as the fraction of total growth removed was almost three times greater at lower light. Net phytoplankton growth rates at S4 were not adjusted for photoacclimation. Thus at the lower light intensity, net phytoplankton growth rates may have been over-estimated, if a decrease in light resulted in phytoplankton increasing their cellular pigment content. This lack of adjustment, however, does not change our conclusions that light did not influence mesozooplankton-grazing rates. Indeed any photoacclimation process would have affected net phytoplankton growth rates in all treatments similarly, and thus differences between the copepod treatments and the controls with or without adjustment would remain unchanged. On the other hand, if the net phytoplankton growth rates were overestimated at the low light intensity, then the difference in net growth rates between the high and the low light treatments may have been underestimated, magnifying the greater effect of light than of grazing on phytoplankton accumulation. The differential effect of light on growth and grazing rates observed here suggests that in the ocean, the exponential decrease of light with depth acts to decouple growth and grazing, resulting in a vertically increasing grazing impact on PP.

\section{Conclusions}

Concurrent investigation of mesozooplankton and microzooplankton grazing impact on phytoplankton primary production in the western North Atlantic suggested a generally limited potential control of phytoplankton biomass by herbivorous copepods, sometimes but not always exceeded by microzooplankton grazing. Although the observations reported here were acquired opportunistically and are limited in sampling scope, they represent a diverse range of environmental conditions and species composition from a poorly sampled region. The generally low mesozooplankton grazing impact across stations despite the spatial diversity of species and conditions, as well as the good agreement with similar studies in other regions, provide important constraints to quantifying grazer-induced phytoplankton mortality rates for this region and the NAAMES spring campaign. There was no indication of preferential feeding on microzooplankton by larger copepods. Remarkably, when compared, light effects on net phytoplankton growth rates exceeded mesozooplankton grazing effects by at least 3-fold. Together these coupled biological and environmental effects provide insights into the transfer and recycling of recently fixed carbon. Specifically, they suggest limited vertical export of phytoplankton production as mediated by large zooplankton. Such concurrent environmental and 
574 biological process data on controls of primary production provide important parameters for

575

576

577

578

579

580

581

582

583

584

585

586

587

588

589

590

591

592

593

594

595

596

597

598

599

600

601

602

603

604

605

606

607

608

609

610

611

612

613

614

615

616

617

618

619

modeling frameworks assessing global elemental fluxes and carbon export.

\section{Acknowledgements}

The authors appreciate the support from the Captain and Crew of the R/V Atlantis during cruise AT34 in 2016 and leadership from Chief Scientist Mike Behrenfeld (Oregon State University). We thank Peter Gaube and Alice Dellapenna (University of Washington Applied Physics Lab) for sharing their assessment of the eddy field, Pierre Marrec for help with figures, and Amanda Montalbano for excellent logistical support.

\section{References}

Anderson, S.R., and Menden-Deuer, S. (2017). Growth, Grazing, and Starvation Survival in Three Heterotrophic Dinoflagellate Species. Journal of Eukaryotic Microbiology 64(2): 213-225. doi: $10.1111 /$ jeu. 12353

Atkinson, A., Ward, P., Williams, R. and Poulet, S.A. (1992). Feeding rates and diel vertical migration of copepods near South Georgia: comparison of shelf and oceanic sites. Marine Biology, 114(1): 49-56.

Banse, K. (1994). Grazing and zooplankton production as key controls of phytoplankton production in the open ocean. Oceanography 7:13-20.

Banse, K. (2013). Reflections About Chance in My Career, and on the Top-Down Regulated World. Annual Review of Marine Science 5(1), 1-19. doi: 10.1146/annurev-marine121211-172359

Barquero, S., Cabal, J.A., Anadón, R., Fernández, E., Varela, M., and Bode, A. (1998). Ingestion rates of phytoplankton by copepod size fractions on a bloom associated with an off-shelf front off NW Spain. Journal of Plankton Research 20(5): 957-972. doi: 10.1093/plankt/20.5.957

Basedow, S. L., Tande, K. S., Norrbin, M. F., and Kristiansen, S. (2013). Capturing quantitative zooplankton information in the sea: performance test of laser optical plankton counter and video plankton recorder in a Calanus finmarchicus dominated summer situation. Progress in Oceanography 108: 72-80. doi: 10.1016/j.pocean.2012.10.005

Behrenfeld, M.J., and Boss, E.S. (2014). Resurrecting the Ecological Underpinnings of Ocean Plankton Blooms. Annual Review of Marine Science 6(1): 167-194. doi: 10.1146/annurev-marine-052913-021325

Behrenfeld, M.J., Moore, R.H., Hostetler, C.A., Graff, J., Gaube, P., Russell, L.M., Chen, G., Doney, S.C., Giovannoni, S., Liu, H., Proctor, C., Bolaños, L.M., Baetge, N., DavieMartin, C., Westberry, T.K., Bates, T.S., Bell, T.G., Bidle, K.D., Boss, E.S., Brooks, S.D., Cairns, B., Carlson, C., Halsey, K., Harvey, E.L., Hu, C., Karp-Boss, L., Kleb, M., Menden-Deuer, S., Morison, F., Quinn, P.K., Scarino, A.J., Anderson, B., Chowdhary, J., Crosbie, E., Ferrare, R., Hair, J.W., Hu, Y., Janz, S., Redemann, J., Saltzman, E., Shook, M., Siegel, D.A., Wisthaler, A., Yang Martin, M., and Ziemba, L. (2019). The North Atlantic Aerosol and Marine Ecosystem Study (NAAMES): Science Motive and Mission Overview. Frontiers in Marine Science 6(122). doi: 10.3389/fmars.2019.00122

Beisner, B.E., Grossari, H.-P. and Gasol, J.M. (2019) A guide to methods for estimating phagomixotophy in nanophytoplankton. Journal of Plankton Research 41: 77-89. 
620 Burkill, P.H., Mantoray, R.F.C., Llewellyn, C.A., and Owens, N.J.P. (1987). Microzooplankton

621

622

623

624

625

626

627

628

629

630

631

632

633

634

635

636

637

638

639

640

641

642

643

644

645

646

647

648

649

650

651

652

653

654

655

656

657

658

659

660

661

662

663 grazing and selectivity of phytoplankton in coastal water. Marine Biology 93: 581-590.

Burkill, P.H., Edwards, E.S., John, A.W.G., and Sleigh, M.A. (1993). Microzooplankton and their herbivorous activity in the northeastern Atlantic Ocean. Deep Sea Research Part II: Topical Studies in Oceanography 40(1): 479-493. doi: 10.1016/0967-0645(93)90028-L

Calbet, A. (2001). Mesozooplankton grazing effect on PP: A global comparative analysis in marine ecosystems. Limnology and Oceanography 46(7): 1824-1830. doi: $10.4319 / 10.2001 .46 .7 .1824$

Calbet, A. (2008). The trophic role of microzooplankton in marine systems. ICES Journal of Marine Science 65: 325-331

Calbet, A., Atienza, D., Henriksen, C.I., Saiz, E., and Adey, T.R. (2009). Zooplankton grazing in the Atlantic Ocean: A latitudinal study. Deep Sea Research Part II: Topical Studies in Oceanography 56(15): 954-963. doi: 10.1016/j.dsr2.2008.10.009

Calbet, A., and Landry, M.R. (2004). Phytoplankton growth, microzooplankton grazing, and carbon cycling in marine systems. Limnology and Oceanography 49(1): 51-57. doi: 10.4319/1o.2004.49.1.0051

Calbet, A., and Saiz, E. (2005). The ciliate-copepod link in marine ecosystems. Aquatic Microbial Ecology 38(2): 157-167.

Calbet, A., Martínez, R.A., Isari, S., Zervoudaki, S., Nejstgaard, J.C., Pitta, P., Sazhin, A.F., Sousoni, D., Gomes, A., Berger, S.A., Tsagaraki, T.M., and Ptacnik, R. (2012) Effects of light availability on mixotrophy and microzooplankton grazing in an oligotrophic plankton food web: evidences from a mesocosm study in eastern mediterranean waters. Journal of Experimental Marine Biology and Ecology 424: 66-77. doi: 10.1016/j.jembe.2012.05.005.

Campbell, R.G., Sherr, E.B., Ashjian, C.J., Plourde, S., Sherr, B.F., Hill, V., and Stockwell, D.A. (2009). Mesozooplankton prey preference and grazing impact in the western Arctic Ocean. Deep Sea Research Part II: Topical Studies in Oceanography 56(17): 1274-1289. doi: $10.1016 / \mathrm{j}$.dsr2.2008.10.027.

Castellani, C., Irigoien, X., Mayor, D.J., Harris, R.P., and Wilson, D. (2008). Feeding of Calanus finmarchicus and Oithona similis on the microplankton assemblage in the Irminger Sea, North Atlantic. Journal of Plankton Research 30(10): 1095-1116. doi: 10.1093/plankt/fbn074

Chen, B. (2015). Assessing the accuracy of the "two-point" dilution technique. Limnology and Oceanography Methods 13: 521-526. doi:10.1002/lom3.10044

Cieri, M.D., and Stearns, D.E. (1999). Reduction of grazing activity of two estuarine copepods in response to the exudate of a visual predator. Marine Ecology Progress Series 177: 157163. doi: $10.3354 /$ meps 177157

Cowles, T.J. (1979). The feeding response of copepods from the Peru upwelling system: food size selection. Journal of Marine Research 13: 601-622.

Cowles, T.J., and Fessenden, L.M. (1995). Copepod grazing and fine-scale distribution patterns during the Marine Light-Mixed Layers experiment. Journal of Geophysical Research 100(C4): 6677-6686. doi: 10.1029/94jc02214

Cushing, D.H. (1959). The seasonal variation in oceanic production as a problem in population dynamics. ICES Journal of Marine Science 24: 455-464, doi: 10.1093/icesjms/24.3.455 
664 Dam, H.G., Miller, C.A., and Jonasdottir, S.H. (1993). The trophic role of mesozooplankton at

665

666

667

668

669

670

671

672

673

674

675

676

677

678

679

680

681

682

683

684

685

686

687

688

689

690

691

692

693

694

695

696

697

698

699

700

701

702

703

704

705

706

707

708 $47^{\circ} \mathrm{N}, 20^{\circ} \mathrm{W}$ during the North Atlantic Bloom Experiment. Deep Sea Research Part II: Topical Studies in Oceanography 40(1): 197-212. doi: 10.1016/0967-0645(93)90013-D

Della Penna, A., and Gaube, P. (2019). Overview of (Sub)mesoscale Ocean Dynamics for the NAAMES field program. Frontiers in Marine Science 6:384. doi: 10.3389/fmars.2019.00384

Ducklow, H.W., Steinberg, D.K., Buesseler, K.O. (2001). Upper ocean carbon export and the biological pump. Oceanography 14(4): 50-58. doi: 10.5670/oceanog.2001.16

Durbin, A.G., Durbin, E.G. and Wlodarczyk, E. (1990). Diel feeding behavior in the marine copepod Acartia tonsa in relation to food availability. Marine Ecology Progress Series 68: 23-45.

Durbin, E.G., Campbell, R.G., Gilman, S.L. and Durbin, A.G. (1995). Diel feeding behavior and ingestion rate in the copepod Calanus finmarchicus in the southern Gulf of Maine during late spring. Continental Shelf Research 15(4-5): 539-570.

Eilertsen, H.C., Tande, K.S., and Taasen, J.P.J.P.B. (1989). Vertical distributions of PP and grazing by Calanus glacialis jaschnov and $\mathrm{C}$. hyperboreus krøyer in Arctic waters (Barents Sea). Polar Biology 9(4): 253-260. doi: 10.1007/bf00263773.

Evans, G.T., and Parslow, J.S. (1985). A model of annual plankton cycles. Biological Oceanography 3:327-347.

Frost, B.W. (1972). Effects of size and concentration of food particles on the feeding behavior of them arine planktonic copepod Calanus pacificus. Limnology and Oceanography 17(6): 805-815. doi: 10.4319/1o.1972.17.6.0805

Genin, A., Jaffe, J.S., Reef, R., Richter, C., and Franks, P.J.S. (2005). Swimming Against the Flow: A Mechanism of Zooplankton Aggregation. Science 308(5723): 860-862. doi: 10.1126/science. 1107834

Gifford, D.J. (1993). Protozoa in the diets of Neocalanus spp. in the oceanic subarctic Pacific Ocean. Progress in Oceanography 32(1): 223-237. doi: 10.1016/0079-6611(93)90015-6

Gifford, D.J., Fessenden, L.M., Garrahan, P.R., and Martin, E. (1995). Grazing by microzooplankton and mesozooplankton in the high-latitude North Atlantic Ocean: Spring versus summer dynamics. Journal of Geophysical Research 100(C4): 6665-6675. doi: $10.1029 / 94 j \mathrm{jc} 00983$

Gleiber, M.R., Steinberg, D.K., and Ducklow, H.W. (2012). Time series of vertical flux of zooplankton fecal pellets on the continental shelf of the western Antarctic Peninsula. Marine Ecology Progress Series 471:23-36.

Gonçalves, R.J., van Someren Gréve, H., Couespel, D., and Kiørboe, T. (2014). Mechanisms of prey size selection in a suspension-feeding copepod, Temora longicormis. Marine Ecology Progress Series 517: 61-74.

Graff, J.R., and Behrenfeld, M.J. (2018). Photoacclimation responses in subarctic Atlantic phytoplankton following a natural mixing-restratification event. Frontiers Marine Science 5:209. doi: 10.3389/fmars.2018.00209

Graff, J.R., and Rynearson, T.A. (2011). Extraction method influences the recovery of phytoplankton pigments from natural assemblages. Limnology and Oceanography Methods 9(4): 129-139. doi: 10.4319/lom.2011.9.129

Gutierrez-Rodriguez, A., Latasa, M., Agustí, S., and Duarte, C. M. (2011). Distribution and contribution of major phytoplankton groups to carbon cycling across contrasting 
722

723

724

725

726

727

728

729

730

731

732

733

734

735

736

737

738

739

740

741

742

743

744

745

746

747

748

749

750

751

752

753

754

conditions of the subtropical northeast Atlantic Ocean. Deep Sea Research Part I 58: 1115-1129. doi: 10.1016/j.dsr.2011.08.003

Gutiérrez-Rodríguez, A., M. Latasa, M. Estrada, M. Vidal, and C. Marrasé. (2010). Carbon fluxes through major phytoplankton groups during the spring bloom and post-bloom in the Northwestern Mediterranean Sea. Deep Sea Research Part I 57: 486-500. doi:10.106/j.dsr.2009.12.013

Halvorsen, E., Hirst, A.G., Batten, S.D., Tande, K.S., and Lampitt, R.S. (2001). Diet and community grazing by copepods in an upwelled filament off the NW coast of Spain. Progress in Oceanography 51(2): 399-421. doi: 10.1016/S0079-6611(01)00077-5

Hansen, B., Tande, K.S. and Berggreen, U.C. (1990). On the trophic fate of Phaeocystis pouchetii (Harlot). III. Functional responses in grazing demonstrated on juvenile stages of Calanus finmarchicus (Copepoda) fed diatoms and Phaeocystis. Journal of Plankton Research, 12(6): 1173-1187.

Heath, M.R., Boyle, P.R., Gislason, A., Gurney, W.S.C., Hay, S.J., Head, E.J.H., Holmes, S., Ingvarsdóttir, A., Jónasdóttir, S.H., Lindeque, P., Pollard, R.T., Rasmussen, J., Richards, K., Richardson, K., Smerdon, G., and Speirs, D. (2004) Comparative ecology of overwintering Calanus finmarchicus in the North Atlantic and implications for life cycle patterns. ICES Journal of Marine Science 61: 698-708. doi: 10.1016/j.icesjms.2004.03.013.

Hirche, H.J., Baumann, M.E.M., Kattner, G., and Gradinger, R. (1991). Plankton distribution and the impact of copepod grazing on PP in Fram Strait, Greenland Sea. Journal of Marine Systems 2(3): 477-494. doi: 10.1016/0924-7963(91)90048-Y

Hirche, H.J., Muyakshin, S., Klages, M., and Auel, H. (2006). Aggregation of the Arctic copepod Calanus hyperboreus over the ocean floor of the Greenland Sea. Deep Sea Research Part I: Oceanographic Research Papers 53(2): 310-320. doi: 10.1016/j.dsr.2005.08.005

Holte, J., and Talley, L. (2009). A New Algorithm for Finding Mixed Layer Depths with Applications to Argo Data and Subantarctic Mode Water Formation. Journal of Atmospheric and Oceanic Technology 26(9): 1920-1939. doi: 10.1175/2009jtecho543.1

Huntley, M. and Tande, K. (1987). On the trophic fate of Phaeocystis pouchetii (Hariot). II. Grazing rates of Calanus hyperboreus (Krøyer) on diatoms and different size categories of Phaeocystis pouchetii. Journal of Experimental Marine Biology and Ecology, 110(3): pp.197-212.

Jespersen, A.M., and Christoffersen, K. (1987). Measurements of chlorophyll a from phytoplankton using ethanol as extraction solvent. Archiv für Hydrobiologie 109(3): 445454.

Kiørboe, T. (2011). How zooplankton feed: mechanisms, traits and trade-offs. Biological Reviews 86: 311-339. doi: 10.1111/j.1469-185X.2010.00148.x

Kleppel, G.S. (1993). On the diets of calanoid copepods. Marine Ecology Progress Series 99: 183-195.

Landry, M. R., and Hassett, R. P. (1982). Estimating the grazing impact of marine microzooplankton. Marine Biology 67: 283-288. doi: 10.1007/bf00397668

Landry, M.R., Brown, S.L., Rii, Y.M., Selph, K.E., Bidigare, R.R., Yang, E.J., and Simmons, M.P. (2008). Depth-stratified phytoplankton dynamics in Cyclone Opal, a subtropical mesoscale eddy. Deep Sea Research Part II: Topical Studies in Oceanography 55(10): 1348-1359. doi: 10.1016/j.dsr2.2008.02.001

PeerJ reviewing PDF | (2020:02:45907:2:0:NEW 2 Jun 2020) 
755

756

757

758

759

760

761

762

763

764

765

766

767

768

769

770

771

772

773

774

775

776

777

778

779

780

781

782

783

784

785

786

787

788

789

790

791

792

793

794

795

796

797

798

799

Landry, M.R., Constantinou, J., and Kirshtein, J. (1995). Microzooplankton grazing in the central equatorial Pacific during February and August, 1992. Deep Sea Research Part II 42: 657671. doi: 10.1016/0967-0645(95) 00024- K

Landry, M.R., Ohman, M.D., Goericke R., Stukel M.R., and Tsyrklevich, K. (2009). Lagrangian studies of phytoplankton growth and grazing relationships in a coastal upwelling ecosystem off Southern California. Progress in Oceanography 83: 208-216. doi:10.1016/j.pocean.2009.07.026

Landry, M.R., Selph, K.E., Taylor, A.G., De cima, M., Balch, W.M., and Bidigare, R.R. (2011). Phytoplankton growth, grazing and production balances in the HNLC equatorial Pacific. Deep-Sea Research Part II 58: 524-535. doi:10.1016/j.dsr2.2010. 08. 011

Lavrentyev, P.J., Franzè, G., Pierson, J.J., and Stoecker, D.K. (2015). The effect of dissolved polyunsaturated aldehydes on microzooplankton growth rates in the Chesapeake Bay and Atlantic coastal waters. Marine Drugs 13(5): 2834-2856. doi: 10.3390/md13052834

Lawrence, C., and Menden-Deuer, S. (2012). Drivers of protistan grazing pressure: Seasonal signals of plankton community composition and environmental conditions. Marine Ecology Progress Series 459: 39-52. doi:10.3354/meps09771

Leinaas, H.P., Jalal, M., Gabrielsen, T.M. and Hessen, D.O. (2016). Inter- and intraspecific variation in body- and genome size in calanoid copepods from temperate and arctic waters. Ecology and evolution, 6(16): 5585-5595. doi: 10.1002/ece3.2302

Leising, A.W., Horner, R., Pierson, J.J., Postel, J., and Halsband-Lenk, C. (2005a). The balance between microzooplankton grazing and phytoplankton growth in a highly productive estuarine fjord. Progress in Oceanography 67(3): 366-383. doi: 10.1016/j.pocean.2005.09.007

Leising, A.W., Pierson, J.J., Halsband-Lenk, C., Horner, R., and Postel, J. (2005b). Copepod grazing during spring blooms: Can Pseudocalanus newmani induce trophic cascades? Progress in Oceanography 67(3): 406-421. doi: 10.1016/j.pocean.2005.09.009

Lenz, J., Morales, A., and Gunkel, J. (1993). Mesozooplankton standing stock during the North Atlantic spring bloom study in 1989 and its potential grazing pressure on phytoplankton: a comparison between low, medium and high latitudes. Deep Sea Research Part II, 40(1): 559-572. doi: 10.1016/0967-0645(93)90032-I

Levinsen, H., Turner, J.T., Nielsen, T.G., and Hansen, B.W. (2000). On the trophic coupling between protists and copepods in arctic marine ecosystems. Marine Ecology Progress Series 204: 65-77.

Löder, M.G.J., Meunier, C., Wiltshire, K.H., Boersma, M., and Aberle, N. (2011). The role of ciliates, heterotrophic dinoflagellates and copepods in structuring spring plankton communities at Helgoland Roads, North Sea. Marine Biology 158: 1551-1580

Madsen, S.D., Nielsen, T., and Hansen, B.W. (2001). Annual population development and production by Calanus finmarchicus, C. glacialis and C. hyperboreus in Disko Bay, western Greenland. Marine Biology 139:75-93.

Mayor D.J., Anderson, T.R., Irigoien, X., and Harris, R. (2006). Feeding and reproduction of Calanus finmarchicus during non bloom conditions in the Irminger Sea. Journal of Plankton Research 28(12), 1167-1179. doi: 10.1093/plankt/fbl047

Menden-Deuer, S., Lawrence, C., and Franzè, G. (2018). Herbivorous protist growth and grazing rates at in situ and artificially elevated temperatures during an Arctic phytoplankton spring bloom. PeerJ 6, e5264. doi: 10.7717/peerj.5264

Peer] reviewing PDF | (2020:02:45907:2:0:NEW 2 Jun 2020) 
800

801

802

803

804

805

806

807

808

809

810

811

812

813

814

815

816

817

818

819

820

821

822

823

824

825

826

827

828

829

830

831

832

833

834

835

836

837

838

839

840

841

842

843

844

Menden-Deuer, S., Lessard, E.J., Satterberg, J., and Grünbaum, D. (2005). Growth rates and starvation survival of three species of the pallium-feeding, thecate dinoflagellate genus Protoperidinium. Aquatic Microbial Ecology 41(2): 145-152.

Meunier, C.L., Boersma, M., Wiltshire, K.H., and Malzahn, A.M. (2016). Zooplankton eat what they need: copepod selective feeding and potential consequences for marine systems. Oikos 125(1): 50-58. doi: 10.1111/oik.02072

Meyer-Harms, B., Irigoien, X., Head, R., and Harris, R. 1999. Selective feeding on natural phytoplankton by Calanus finmarchicus before, during, and after the 1997 spring bloom in the Norwegian Sea. Limnology and Oceanography 44(1): 154-165.

Morales, C.E., Bedo, A., Harris, R.P., and Tranter, P.R.G. (1991). Grazing of copepod assemblages in the north-east Atlantic: the importance of the small size fraction. Journal of Plankton Research 13(2): 455-472. doi: 10.1093/plankt/13.2.455

Morison, F., and Menden-Deuer, S. (2015). Early spring phytoplankton dynamics in the subpolar North Atlantic: The influence of protistan herbivory. Limnology and Oceanography 60(4): 1298-1313. doi: 10.1002/lno.10099

Morison, F., and Menden-Deuer, S. (2017). Doing more with less? Balancing sampling resolution and effort in measurements of protistan growth and grazing-rates. Limnology and Oceanography Methods 15(9): 794-809. doi: 10.1002/lom3.10200

Morison, F., Harvey, E., Franzè, G., and Menden-Deuer, S. (2019). Storm-induced predator-prey decoupling promotes springtime accumulation of North Atlantic phytoplankton. Frontiers in Marine Science 6: 608. doi: 10.3389/fmars.2019.00608

Nejstgaard, J.C., Gismervik, I., and Solberg, P.T. (1997). Feeding and reproduction by Calanus finmarchicus, and microzooplankton grazing during mesocosm blooms of diatoms and the coccolithophore Emiliania huxleyi. Marine Ecology Progress Series 147: 197-217.

Nejstgaard, J.D., Hygum, B.H., Naustvoll, L-J., and Båmstedt, U. (2001). Zooplankton growth, diet and reproductive success compared in simultaneous diatom- and flagellatemicrozooplankton-dominated plankton blooms. Marine Ecology Progress Series 221: 7791.

Nejstgaard, J.C., Naustvoll, L-J., Sazhin, A. (2001). Correcting for underestimation of microzooplankton grazing in bottle incubation experiments with mesozooplankton. Marine Ecology Progress Series 221: 59-75.

Olson, M.B., Evelyn, J.L., Chung Huen, J.W., and Megan, J.B. (2006). Copepod feeding selectivity on microplankton, including the toxigenic diatoms Pseudo-nitzschia spp., in the coastal Pacific Northwest. Marine Ecology Progress Series 326: 207-220.

Omand, M.M., D'Asaro, E.A., Lee, C.M., Perry, M.J., Briggs, N., Cetinić, I., and Mahadevan, A. (2015). Eddy-driven subduction exports particulate organic carbon from the spring bloom. Science 348(6231): 222-225. doi: 10.1126/science.1260062

Riley, G.A. (1946). Factors controlling phytoplankton populations on Georges Bank. Journal of Marine Research 6: 54-72.

Ross, O.N., Geider, R.J, Berdalet, E., Artigas, M.L., and Piera, J. (2011). Modelling the effect of vertical mixing on bottle incubations for determining in situ phytoplankton dynamics. I.

Growth rates. Marine Ecology Progress Series 435: 13-31. doi:10.3354/meps09193

Saiz, E., and Calbet, A. (2011). Copepod feeding in the ocean: scaling patterns, composition of their diet and the bias of estimates due to microzooplankton grazing during incubations. Hydrobiologia 666(1): 181-196. doi: 10.1007/s10750-010-0421-6

PeerJ reviewing PDF | (2020:02:45907:2:0:NEW 2 Jun 2020) 
845 Schmoker, C., Hernández-León, S., and Calbet, A. (2013). Microzooplankton grazing in the

846

847

848

849

850

851

852

853

854

855

856

857

858

859

860

861

862

863

864

865

866

867

868

869

870

871

872

873

874

875

876

877

878

879

880

881

882

883

884

885

886

887

888

889 oceans: impacts, data variability, knowledge gaps and future directions. Journal of Plankton Research 35(4): 691-706. doi: 10.1093/plankt/fbt023

Schnetzer, A., and Steinberg, D. (2002). Natural diets of vertically migrating zooplankton in the Sargasso Sea. Marine Biology 141(1): 89-99. doi: 10.1007/s00227-002-0815-8

Scott, C.L., Kwasniewski, S., Falk-Petersen, S., and Sargent, J.R. (2000). Lipids and life strategies of Calanus finmarchicus, Calanus glacialis and Calanus hyperboreus in late autumn, Kongsfjorden, Svalbard. Polar Biology 23(7): 510-516. doi: $10.1007 / \mathrm{s} 003000000114$

Sherr, E.B., and Sherr, B.F. (2002). Significance of predation by protists in aquatic microbial food webs. A. Van Leeuw. 81: 293-308. doi:10.1023/A:1020591307260

Sherr, E.B., and Sherr, B.F. (2009). Capacity of herbivorous protists to control initiation and development of mass phytoplankton blooms. Aquatic Microbial Ecology 57(3): 253-262.

Sherr, E.B., Sherr, B.F., and Ross, C. (2013). Microzooplankton grazing impact in the Bering Sea during spring sea ice conditions. Deep-Sea Research II 94: 57-67. doi:10.1016/ j.dsr2.2013.03.019

Sherr, E. B., Sherr, B. F., Wheeler, P. A., and Thompson, K. (2003). Temporal and spatial variation in stocks of autotrophic and heterotrophic microbes in the upper water column of the central Arctic Ocean. Deep-Sea Research. I 50: 557- 571. doi:10.1016/S09670637(03)00031-1

Sieburth, J.M., Smetacek, V., and Lenz, J. (1978). Pelagic ecosystem structure: Heterotrophic compartments of the plankton and their relationship to plankton size fractions Limnology and Oceanography 23(6): 1256-1263. doi: 10.4319/lo.1978.23.6.1256

Siegel, D.A., Buesseler, K.O., Behrenfeld, M.J., Benitez-Nelson, C.R., Boss, E., Brzezinski, M.A., Burd, A., Carlson, C.A., D’Asaro, E.A., Doney, S.C., Perry, M.J., Stanley, R.H.R., and Steinberg, D.K. (2016). Prediction of the Export and Fate of Global Ocean Net PP: The EXPORTS Science Plan. Frontiers in Marine Science 3(22). doi: 10.3389/fmars.2016.00022

Steinberg, D.K., Carlson, C.A., Bates, N.R., Goldthwait, S.A., Madin, L.P., and Michaels, A.F. (2000). Zooplankton vertical migration and the active transport of dissolved organic and inorganic carbon in the Sargasso Sea. Deep Sea Research Part I: Oceanographic Research Papers 47(1): 137-158. doi: 10.1016/S0967-0637(99)00052-7

Steinberg, D.K., and Landry, M.R. (2017). Zooplankton and the Ocean Carbon Cycle. Annual Review of Marine Science 9(1): 413-444. doi: 10.1146/annurev-marine-010814-015924

Stemmann, L., and Boss, E. (2012). Plankton and particle size and packaging: From determining optical properties to driving the biological pump. Annual Review in Marine Science 4: 263-290. doi: 10.1146/annurev-marine-120710-100853

Stoecker, D.K., and Pierson, J.J. (2019). Predation on protozoa: its importance to zooplankton revisited. Journal of Plankton Research 41(4): 367-373. doi: 10.1093/plankt/fbz027

Stoecker, D. K., Hansen, P. J., Caron, D. A., and Mitra, A. (2017). Mixotrophy in the marine plankton. Annual Review of Marine Science 9: 311-335. doi: 10.1146/annurev- marine010816- 060617

Strom, S.L., and Fredrickson, K. (2008). Intense stratification leads to phytoplankton nutrient limitation and reduced microzooplankton grazing in the southeastern Bering Sea. DeepSea Research Part II. 55: 1761-1774. doi:10.1016/j.dsr2.2008.04.008

Peer) reviewing PDF | (2020:02:45907:2:0:NEW 2 Jun 2020) 
890

891

892

893

894

895

896

897

898

899

900

901

902

903

904

905

906

907

908

909

910

911

912

913

914

915

Tiselius, P. (1988). Effects of diurnal feeding rhythms, species composition and vertical migration on the grazing impact of calanoid copepods in the Skagerrak and Kattegat. Ophelia 28(3): 215-230. doi: 10.1080/00785326.1988.10430814

Turner, J. (2004). The importance of small planktonic copepods and their roles in pelagic marine food webs. Zoological Studies 43(2): 255-266.

Verity, P.G., Stoecker, D.K., Sieracki, M.E., and Nelson, J.R. (1993). Grazing, growth and mortality of microzooplankton during the 1989 North Atlantic spring bloom at $47^{\circ} \mathrm{N}$, $18^{\circ}$ W. Deep Sea Research Part I: Oceanographic Research Papers 40(9): 1793-1814. doi: 10.1016/0967-0637(93)90033-Y

Verity, P.G., Stoecker, D.K., Sieracki, M.E., and Nelson, J.R. (1996). Microzooplankton grazing of primary production at 140 degree W in the Equatorial Pacific. Deep-Sea Research Part II 43: 1227-1256.

Weeks, A., Conte, M.H., Harris, R.P., Bedo, A., Bellan, I., Burkill, P.H., Edwards, E.S., Harbour, D.S., Kennedy, H., Llewellyn, C., Mantoura, R.F.C., Morales, C.E., Pomroy, A.J., and Turley, C.M. (1993). The physical and chemical environment and changes in community structure associated with bloom evolution: the Joint Global Flux Study North Atlantic Bloom Experiment. Deep-Sea Research II 40(1/2): 347-368.

Williams, R., and Lindley, J.A. (1980). Plankton of the fladen ground during FLEX 76 III. Vertical distribution, population dynamics and production of Calanus finmarchicus (Crustacea: Copepoda). Marine Biology 60(1): 47-56. doi: 10.1007/bf00395605

Wirtz, K. (2012). Who is eating whom? Morphology and feeding type determine the size relation between planktonic grazers and their ideal prey. Marine Ecology Progress Series 445: 112.

Worden, A.Z., and Binder, B.J. (2003). Application of dilution experiments for measuring growth and mortality rates among Prochlorococcus and Synechococcus populations in oligotrophic environments. Aquatic Microbial Ecology 30(2): 159-17 


\section{Table $\mathbf{1}$ (on next page)}

Phytoplankton growth and grazing rates in the western North Atlantic in May 2016.

Chlorophyll a ( $\left.\mathrm{Chl} \mathrm{a}, \mu \mathrm{g} \mathrm{L}^{-1}\right)$ concentration in source water used for the experiments ( $\left.\pm \mathrm{SD}\right)$, light intensity used in the incubations (\% of incoming surface irradiance), and estimated rates of in situ phytoplankton instantaneous growth ( $\mu$ NoN), microzooplankton (mzpkt) grazing $(\mathrm{g})$, net phytoplankton growth rates in nutrient amended $<200 \mu \mathrm{m}$ seawater $(k+N)$, non-amended $<200 \mu \mathrm{m}$ seawater ( $\mathrm{kNN}$ ), and copepod additions ( $\mathrm{k}$ Cop). Rates are given per day \pm one standard deviation of duplicate or triplicate treatments. For copepod treatments, $A, B$, and $C$ represent the different number of copepods added $(A=1, B=3, C=5$ for $C$. hyperboreus, $A=10, B=20, C=40$ for $C$. finmarchicus). $n / d$ means rate was undetermined. 


\begin{tabular}{|c|c|c|c|c|c|c|c|c|c|c|c|c|}
\hline \multirow{2}{*}{ Station } & \multirow{2}{*}{ Date } & \multirow{2}{*}{$\begin{array}{c}\text { Chl a } \\
\left(\mu \mathrm{g} \mathrm{L}^{-1}\right)\end{array}$} & \multirow{2}{*}{$\begin{array}{c}\text { Light } \\
(\%)\end{array}$} & \multicolumn{2}{|c|}{ k No $\operatorname{Cop}\left(d^{-1}\right)$} & \multirow{2}{*}{$\begin{array}{c}\text { Copepod } \\
\text { species }\end{array}$} & \multicolumn{3}{|c|}{$k \operatorname{Cop}\left(d^{-1}\right)$} & \multirow{2}{*}{$\begin{array}{c}\mu \\
\text { NoN } \\
\left(d^{-1}\right)\end{array}$} & \multirow{2}{*}{$\begin{array}{c}\text { mzpkt } \\
\text { grazing } \\
\left(\mathrm{g}, \mathrm{d}^{-1}\right)\end{array}$} & \multirow{2}{*}{$\begin{array}{c}\text { mzpkt \% } \\
\text { PP } \\
\text { consumed }\end{array}$} \\
\hline & & & & $+\mathbf{N}$ & No $\mathbf{N}$ & & $\mathbf{A}$ & B & C & & & \\
\hline 1 & $5 / 19 / 16$ & $2.4(0.26)$ & 10 & $\begin{array}{c}0.09 \\
(0.10)\end{array}$ & $\begin{array}{c}0.02 \\
(0.06)\end{array}$ & C. hyperboreus & $\begin{array}{l}-0.25 \\
(0.21)\end{array}$ & $\begin{array}{l}-0.27 \\
(0.04)\end{array}$ & $\begin{array}{l}-0.40 \\
(0.13)\end{array}$ & $\begin{array}{c}0.39 \\
(0.09)\end{array}$ & $\begin{array}{c}0.38 \\
(0.06)\end{array}$ & 97 \\
\hline 2 & $5 / 21 / 16$ & $2.7(0.11)$ & 10 & $\begin{array}{c}0.67 \\
(0.05) \\
\end{array}$ & $\begin{array}{c}0.61 \\
(0.08) \\
\end{array}$ & C. finmarchicus & $\begin{array}{c}0.35 \\
(0.26) \\
\end{array}$ & $\begin{array}{l}-0.14 \\
(0.11)\end{array}$ & $\begin{array}{l}-0.53 \\
(0.11) \\
\end{array}$ & $\begin{array}{c}0.61 \\
(0.08) \\
\end{array}$ & 0.00 & 0 \\
\hline \multirow{2}{*}{4} & \multirow{2}{*}{$5 / 27 / 16$} & \multirow{2}{*}{$1.4(0.09)$} & 40 & $\begin{array}{c}0.60 \\
(0.10) \\
\end{array}$ & $\begin{array}{c}0.59 \\
(0.08)\end{array}$ & Diverse & $\begin{array}{c}0.51 \\
(0.02) \\
\end{array}$ & - & - & $\begin{array}{c}0.59 \\
(0.08) \\
\end{array}$ & $\mathrm{n} / \mathrm{d}$ & $\mathrm{n} / \mathrm{d}$ \\
\hline & & & 10 & - & $\begin{array}{c}0.30 \\
(0.14) \\
\end{array}$ & Diverse & $\begin{array}{c}0.20 \\
(0.06) \\
\end{array}$ & - & - & - & - & - \\
\hline
\end{tabular}


Figure 1

Location of stations where experiments were performed.

Symbols represent eddy type (diamond= cyclonic eddy, square= anticyclonic eddy). Figure was produced using Ocean Data View software (Schlitzer, R., Ocean Data View, odv. awi.de, 2018).

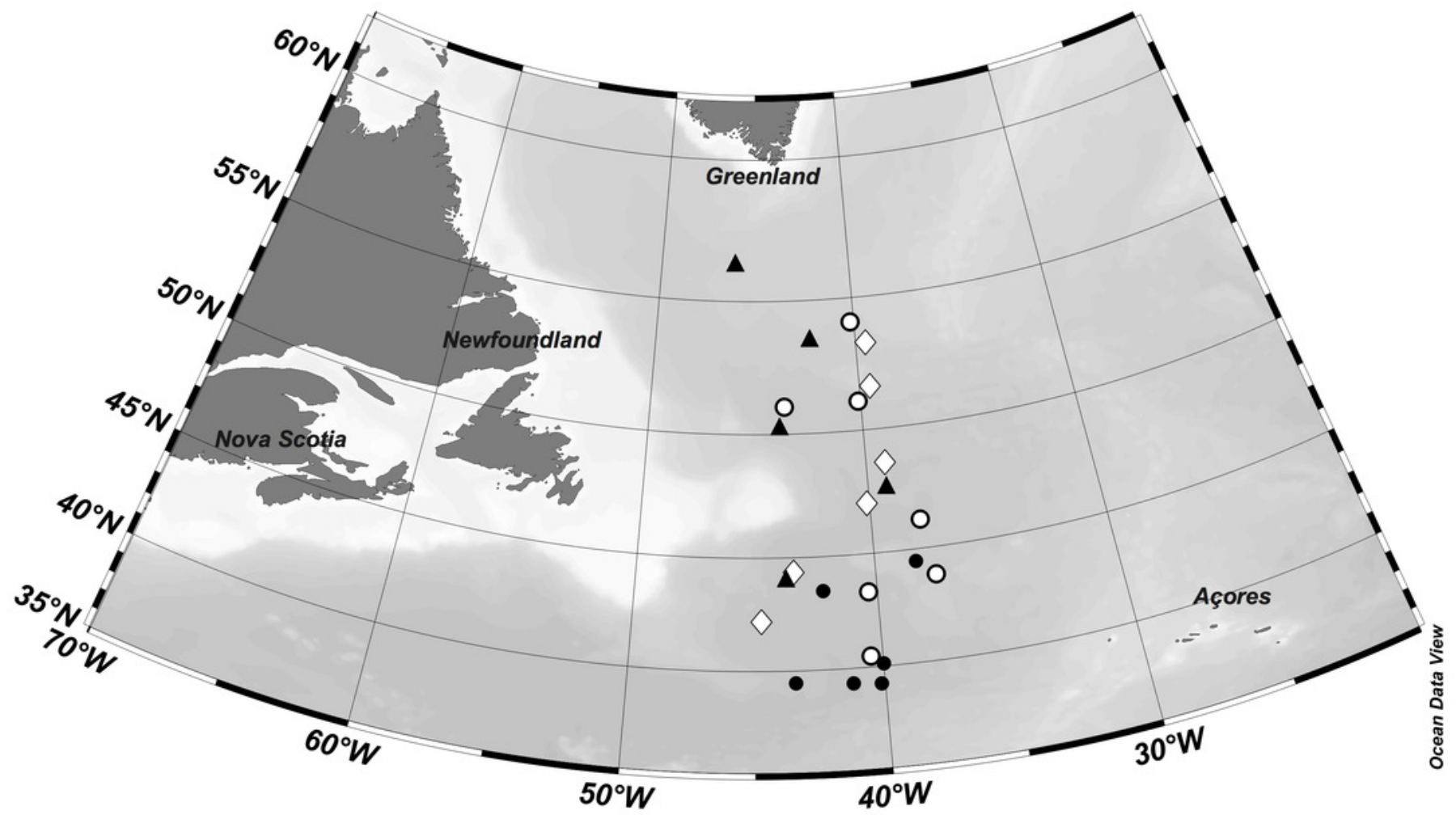


Figure 2

Vertical profiles of physical and biological properties at each sampled station.

Profiles shown include A: temperature, B: salinity, and C: chlorophyll a. Depths, at which water for the experiments was collected, are shown as stars. For best profile definition, temperature and salinity are plotted on the top x-axis for S1 and S2 and on the bottom $\mathrm{x}$-axis for S4. Line style for each variable is the same, with S1 represented by grey solid lines, S2 represented by grey dashed lines, and S4 by thick black lines.

(A)- Temperature $\left({ }^{\circ} \mathrm{C}\right)$

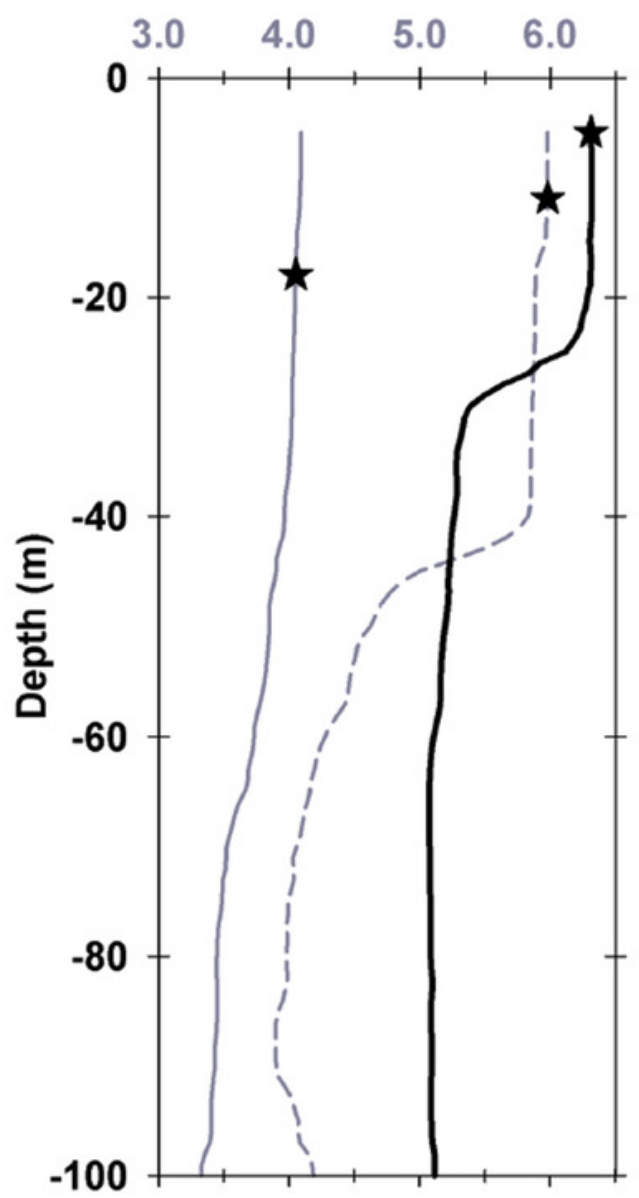

15.0 $\begin{array}{lll}15.2 & 15.4 & 15.6\end{array}$
(B)- Salinity
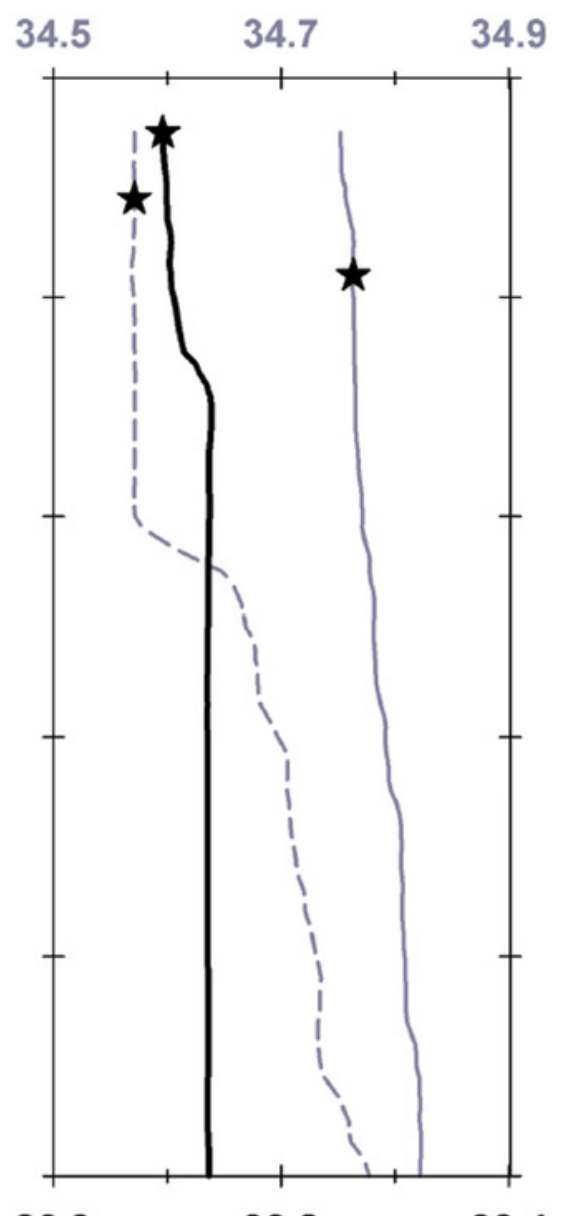

36.0
(C)- Chlorophyll a ( $\left.\mu \mathrm{g} \mathrm{L}^{-1}\right)$

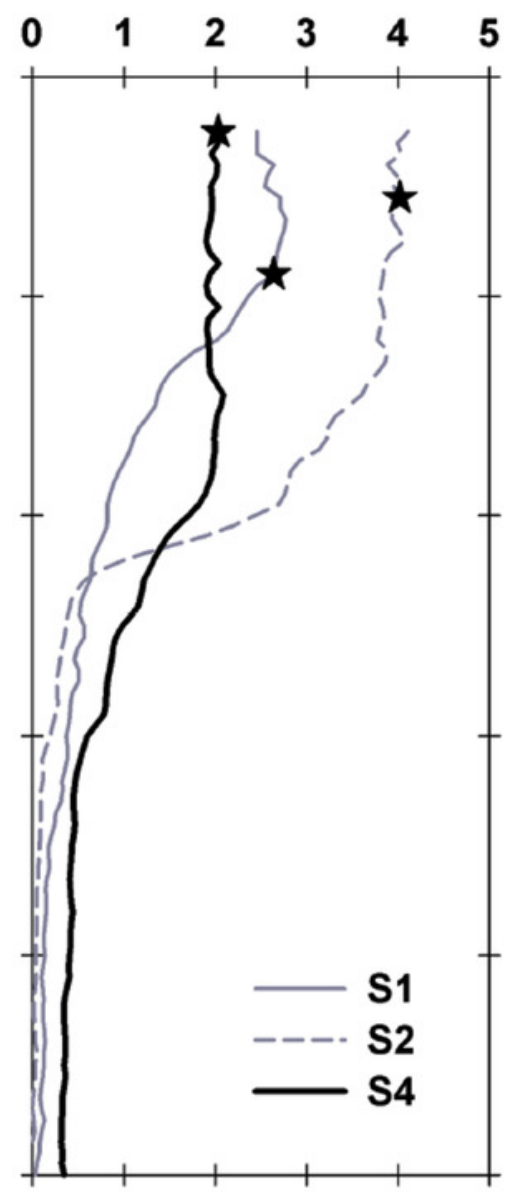


Figure 3

Relative abundance of copepod and mesozooplankton species found at the three sampled stations. 
(A) - Station 1

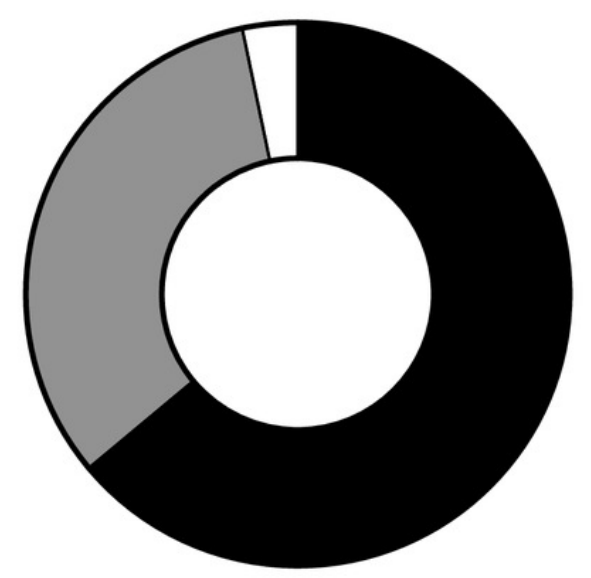

C. finmarchicus

$\square$ C. hyperboreus

$\square$ Metridia lucens

(B) - Station 2

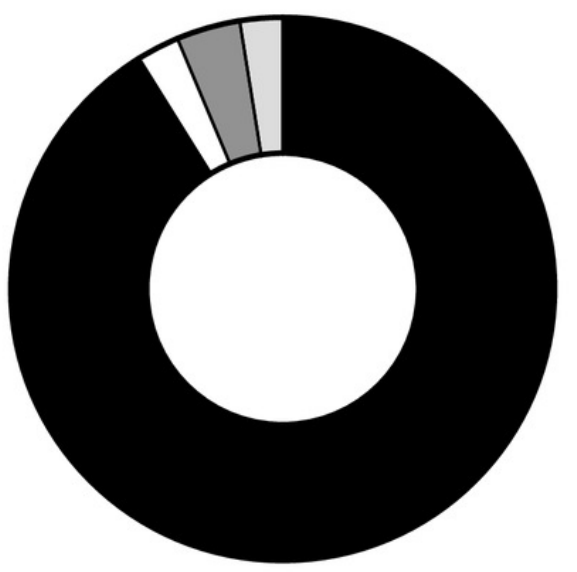

C. finmarchicus

Metridia lucens

Hyperiid amphipods

Others

(C) - Station 4

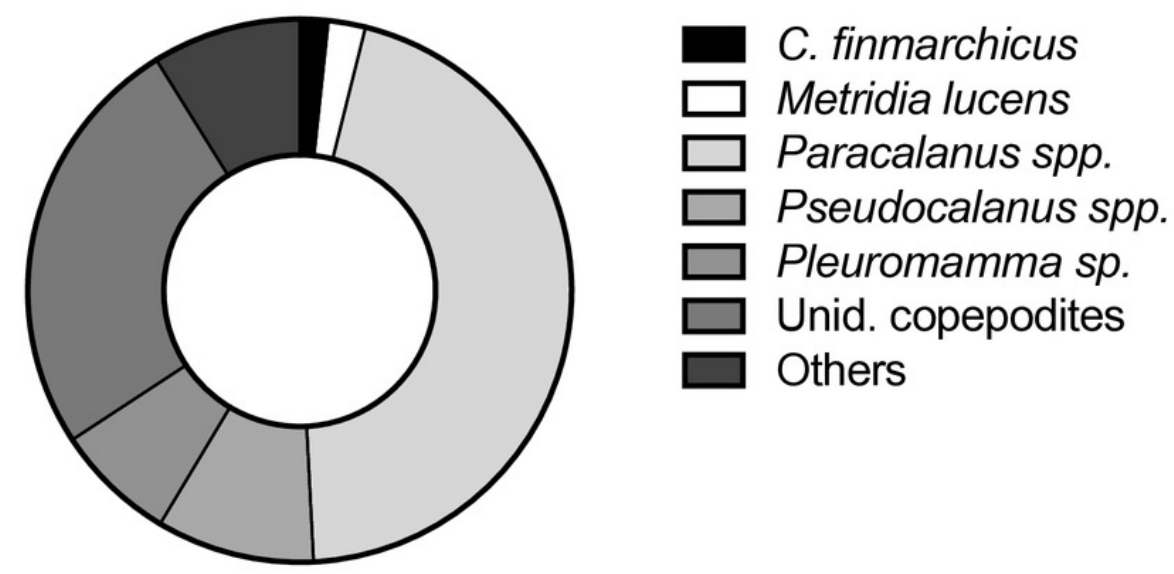




\section{Figure 4}

Net phytoplankton growth rates $\left(k, d^{-1}\right)$ as a function of discrete additions of copepods.

(A) C. hyperboreus, station 1. (B) C. finmarchicus, station 2. Zero copepod treatments correspond to $<200 \mu \mathrm{m}$ undiluted seawater samples from microzooplankton dilution experiments. Significant negative slopes indicate copepod removal of phytoplankton biomass, resulting in reduced net phytoplankton growth. Dashed lines represent slope $95 \%$ confidence interval. 
Station 1

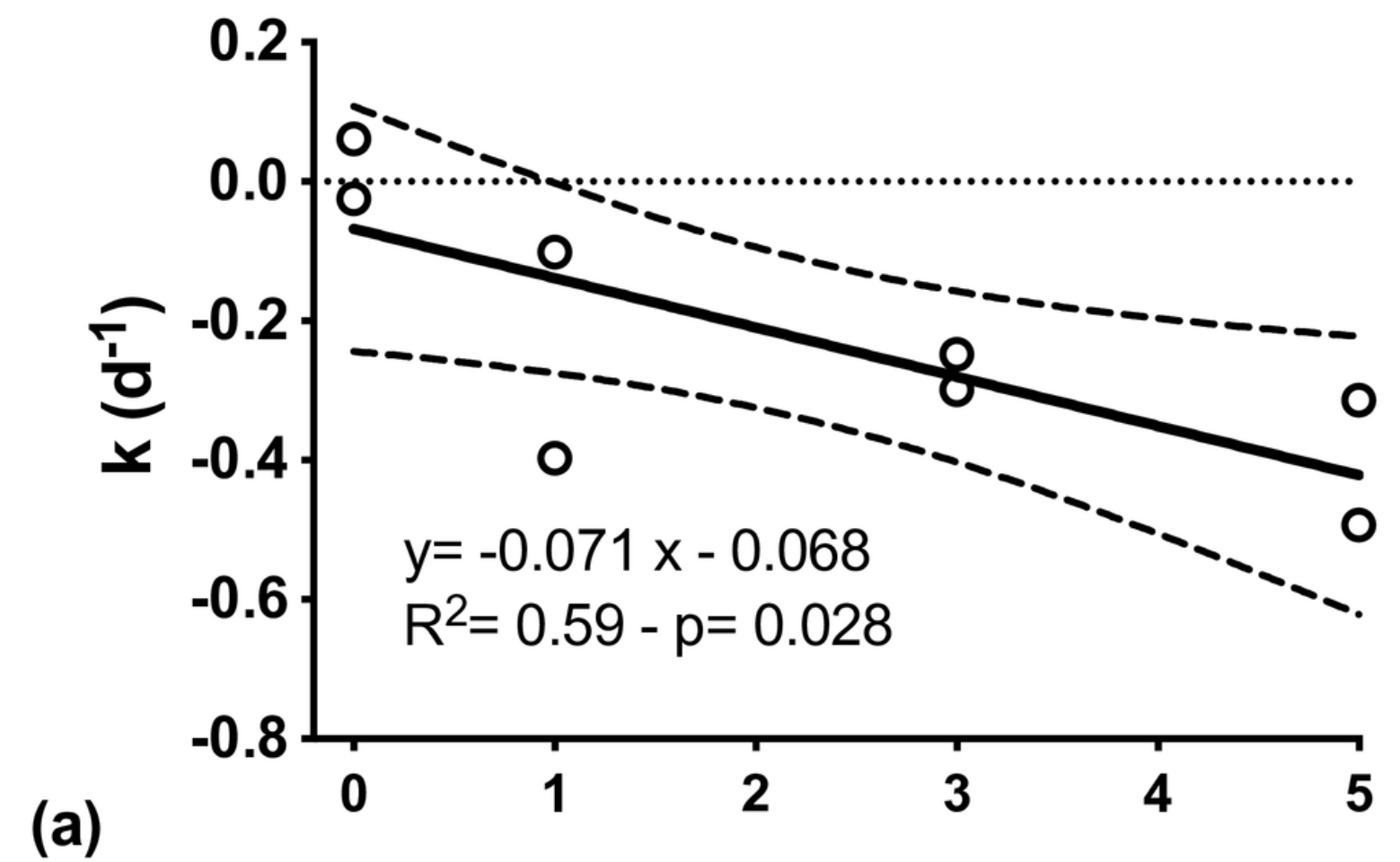

Station 2

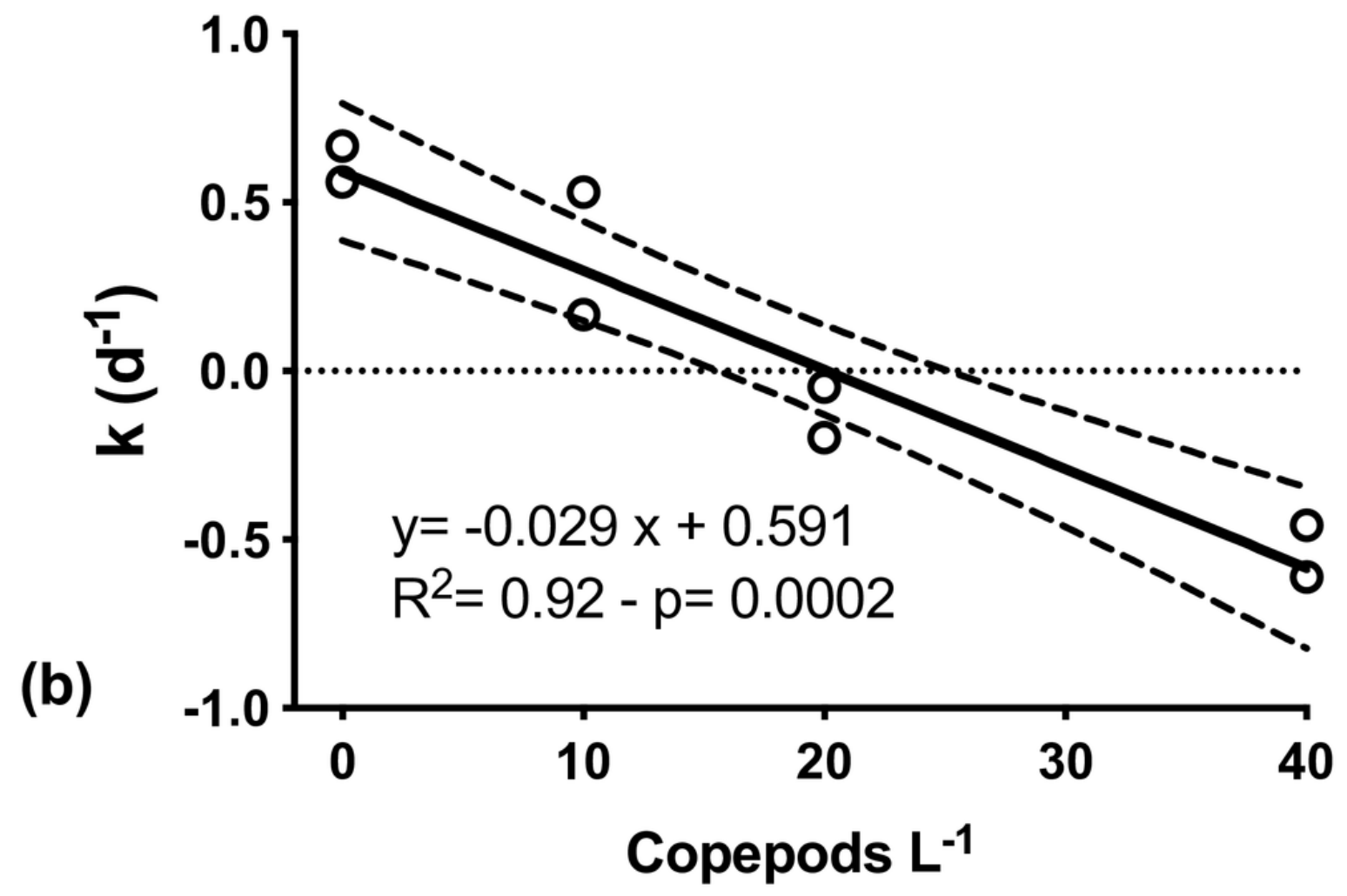


Figure 5

Net phytoplankton growth rates $\left(\mathrm{k}, \mathrm{d}^{-1}\right)$ at Station 4 in relation to light treatment and grazer's type.

Rates are given as mean \pm SD of duplicate (microzooplankton) and triplicate (mesozooplankton) measurements. Low and high light refer to $10 \%$ and $50 \%$ surface irradiance respectively.

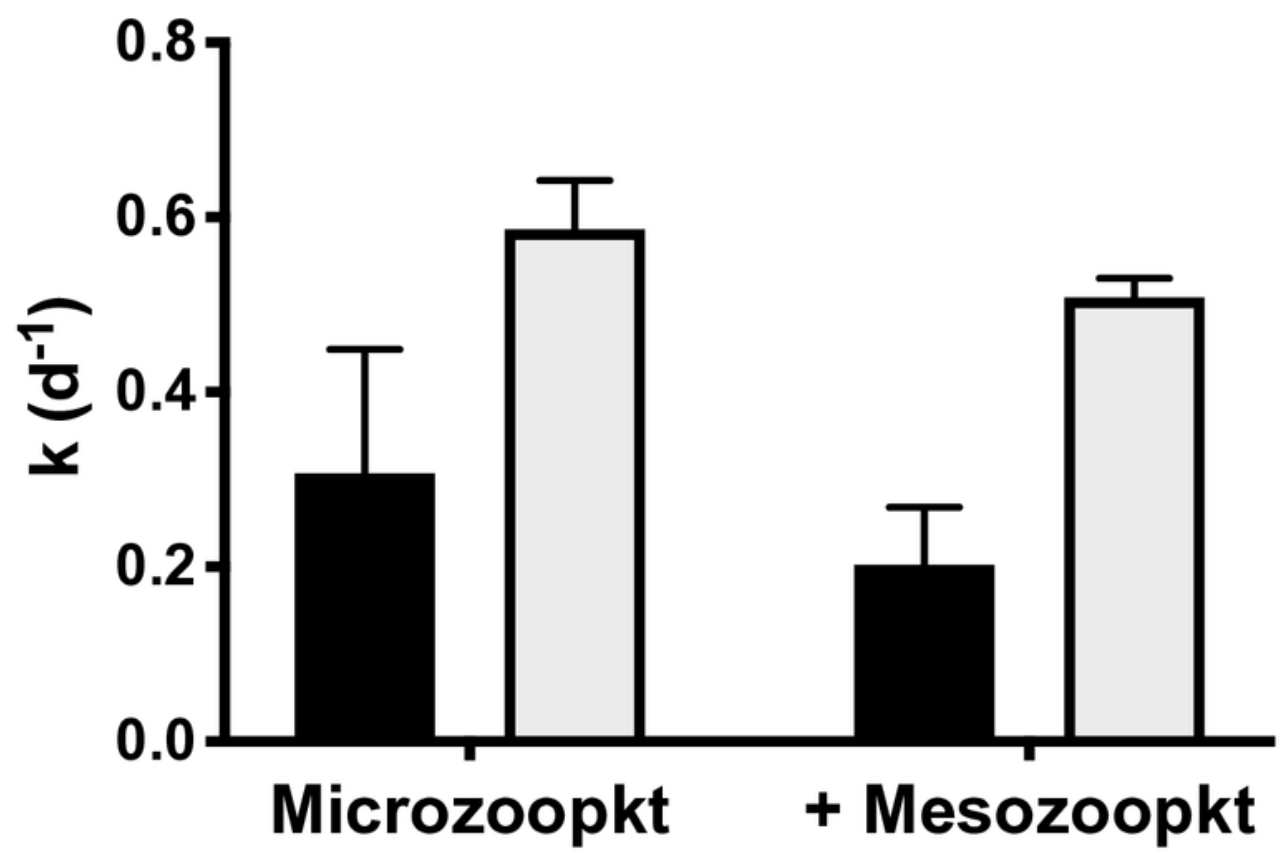

Low light

$\square$ High light 


\section{Figure 6}

Particle abundance $\left(\mathrm{mL}^{-1}\right)$ vs. size as equivalent spherical diameter (ESD), $\left.\mu \mathrm{m}\right)$ at the beginning and at the end of $24 \mathrm{~h}$ incubations with and without mesozooplantkon.

(A) Station 1, one individual of $C$. hyperboreus, (B) Station 2, 20 and 40 individuals of $C$. finmarchicusand (C) Station 4 whole mesozooplankton community ( $>200 \mu \mathrm{m})$ at in situ light intensity ( $\sim 40 \%$ of surface irradiance). For clarity, error bars for replicated samples have been omitted. The variation among replicates depended on size class, with higher variation in the higher size bins, due to low $\left(<5\right.$ particles $\left.\mathrm{mL}^{-1}\right)$ abundance. The average $\mathrm{CV}$ in copepod/mesozooplankton replicates was $11-13 \%$ for particles 3-20 $\mu \mathrm{m}$, with minimum values of $0-3 \%$. 


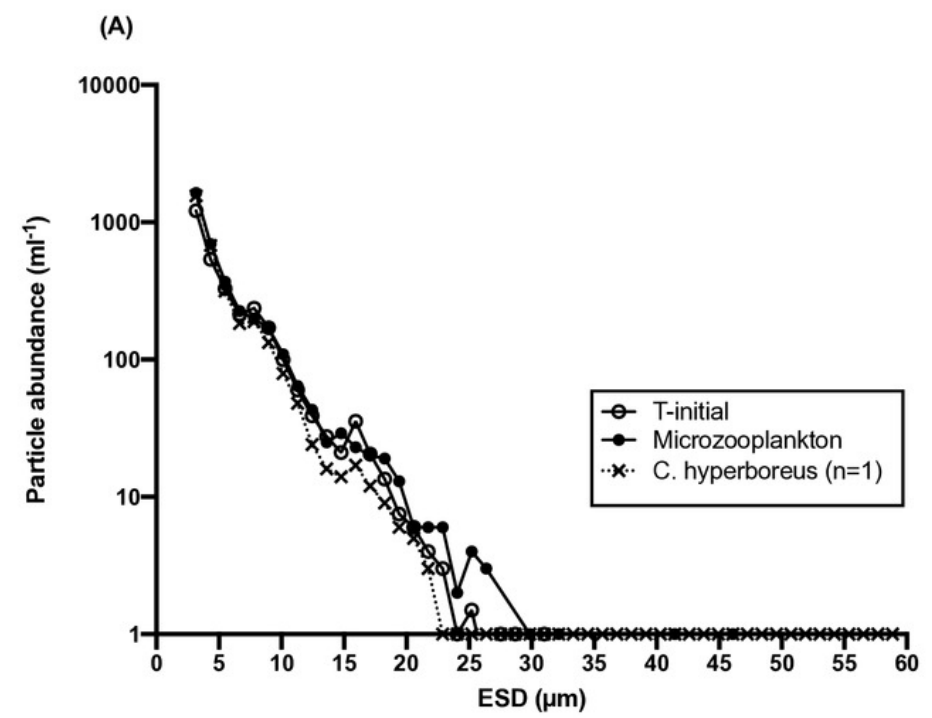

(B)

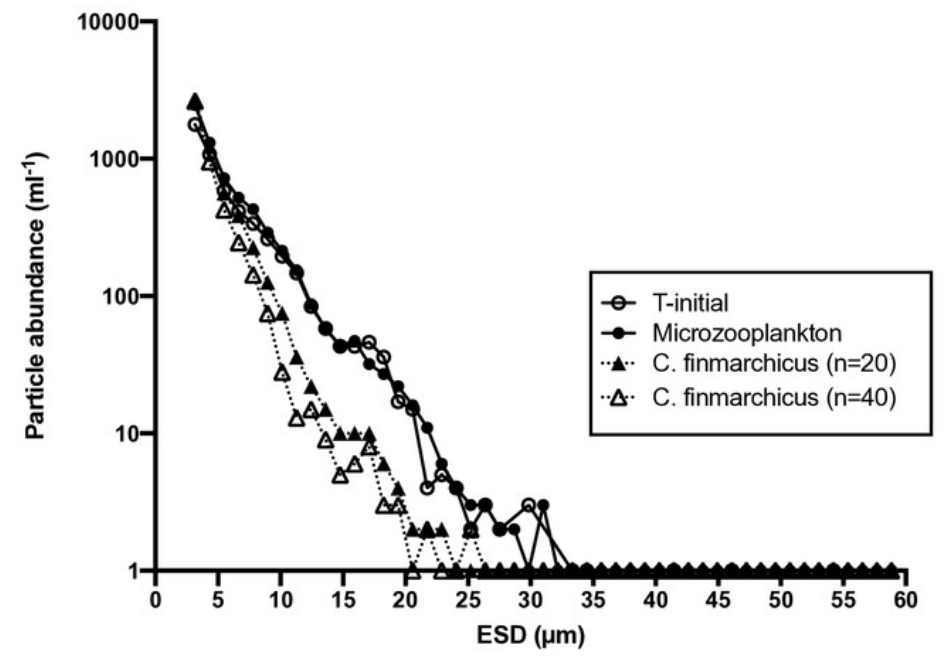

(C)

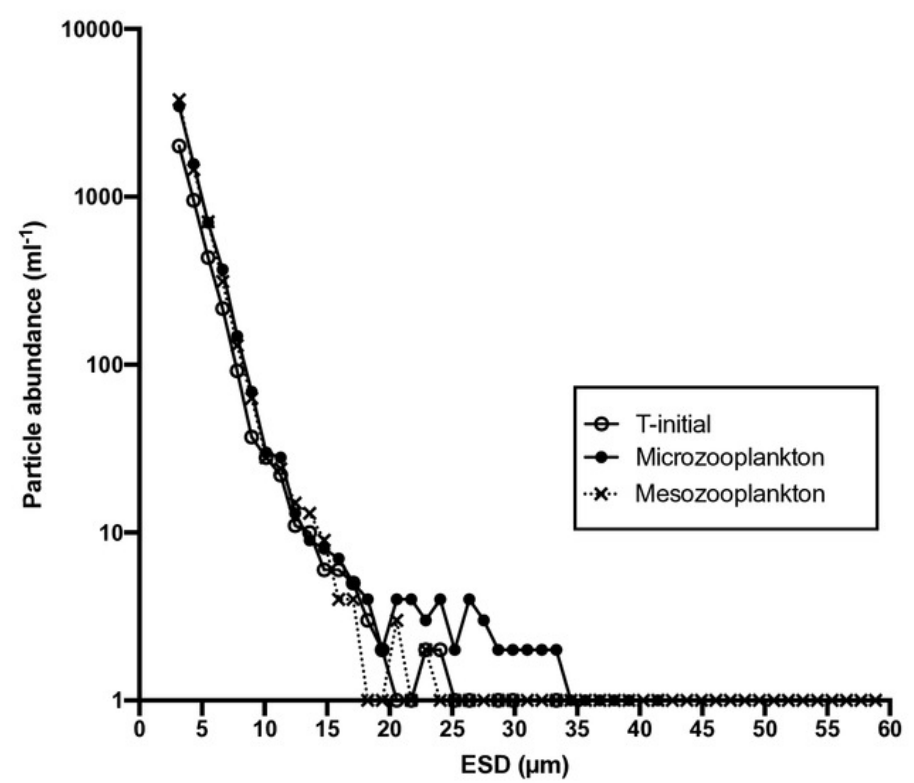

Peer) reviewing PDF | (2020:02:45907:2:0:NEW 2 Jun 2020) 